\title{
European-level Industrial and Class Relations in the Wake of the Eurozone Crisis
}

\author{
by
}

Isaac Alexander Gray

A thesis submitted to the Faculty of Graduate and Postdoctoral Affairs in partial fulfillment of the requirements for the degree of

Master of Arts

in

Political Economy

Carleton University

Ottawa, Ontario

(C) 2015, Isaac Alexander Gray 


\begin{abstract}
The European labour movement has suffered a great number of defeats since the Eurozone Crisis began in October, 2009. In the crisis response, the EU implemented policies that have consistently prioritized the needs of capital over those of the working class. This thesis uses a class-based analysis to contextualize industrial relations at the European level during the Eurozone crisis. It concludes that the outcome of the crisis was grounded in the thirty years that preceded the crisis, during which time neoliberalism was engrained into the formation of the EU. The neoliberal policy set provided capital with a significant structural advantage and tied organize labour to structure in which it was structurally disadvantaged. Fundamentally, the weakness of labour is grounded in its lack structural power at the European level. In order to correct this, labour will have to take steps to build solidarity that is grounded on a common European identity.
\end{abstract}




\section{Acknowledgements}

The research for this thesis was funded by the generous contributions of the Social Sciences and Humanities Research Council, the Carleton University Institute of Political Economy and the Carleton University European Union Centre for Excellence.

This project would not have been possible without the logistical support and intellectual guidance of the Transnational Institute and their staff. I would also like to thank the 29 participants that gave up their time to share their knowledge and expertise. Your generosity and wisdom is inspirational. I would also like to thank the European Trade Union Confederation, Group II of the European Economic and Social Committee, the European Trade Union Institution and the Austrian Chamber of Labour for their hospitality.

I would also like to thank my Supervisor, Dr. Achim Hurrelmann and my second reader, Dr. Teresa Healy. Your ongoing support, patience, encouragement and intellectual guidance was undeserved and critical to my success. This thesis would also not have been possible if Ms. Donna Coghill were any less committed to supporting the students in the Institute of Political Economy.

None of this would have been possible without the unwavering support of my mother, Michele Rigby, my father, Bruce Gray, my siblings, and my extended family.

My good friends, Grant MacNeil, Katelynn Northam, Ana Žbona and David Karrel contributed both as editors and as sources of support, strength and kindness.

For nonacademic reasons, the past few years have been among the most difficult in my life. At points, I did not believe I would finish. It is thanks to all of you that I did.

Thank you all so much.

\section{Dedications}

This work is dedicated to two of the most influential people in my life; my Grandmother, Irma Rigby (1921-2015), and to my oldest friend, Lucas Austin (1985-2014). You were both heroes to me. May you both rest in peace. 


\section{Table of Contents}

European-level Industrial and Class Relations in the Wake of the Eurozone Crisis ................

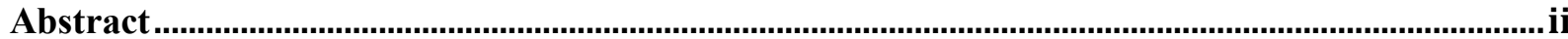

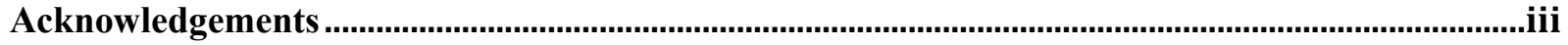

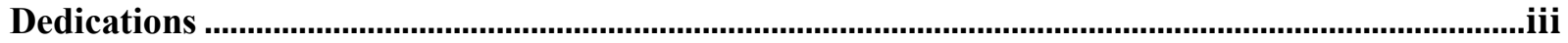

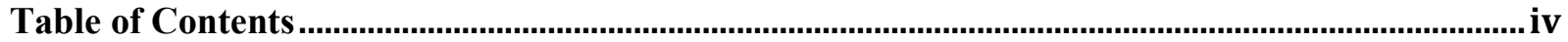

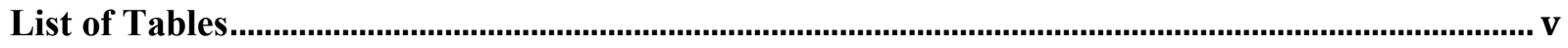

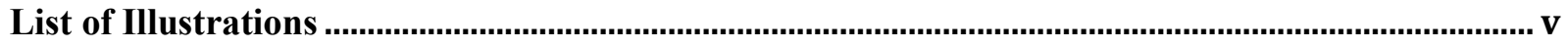

Chapter 1: Understanding Class Struggle During the Eurozone Crisis............................................. 1

Section 1.1: Thesis Overview:..................................................................................................................... 1

Section 1.2: Theoretical Foundations ……………………………………………………………………….. 8

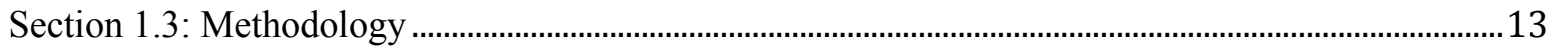

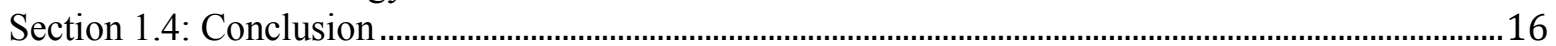

Chapter 2: Theorizing European Industrial and Class Relations ................................................... 19

Section 2.1: Chapter Introduction ...............................................................................................................19

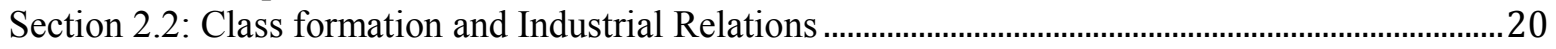

Section 2.3: Capitalism, Liberalism, Class Relations and State Theory ……………………………….23

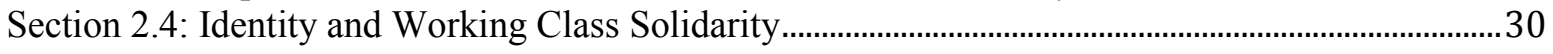

Chapter 3: The Construction of the EU, the Neoliberal Foundation and the Class Relations

Therein. .......................................................................................................................................... 33

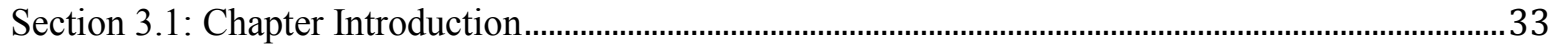

Section 3.2: The Golden Age and the New Push for Integration.............................................................36

Section 3.3: The Creation of the ETUC....................................................................................................4

Section 3.4: From Crisis to Neoliberalism.............................................................................................42

Section 3.5: The European Union and the turn of the Century ……………………………………......4

Chapter 4: The Crisis.............................................................................................................. 58

Section 4.2: The Crisis begins - the Case of Greece .......................................................................................61

Section 4.3: Other Cases of Crisis ...........................................................................................................6

Section 4.3: The Response of Organized Labour …………………………………………………………...... 83

Section 4.4: The Counterweight, Building new Alliances.............................................................................95

Chapter 5: Conclusion ......................................................................................................100

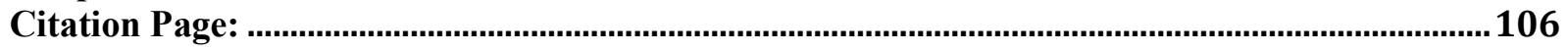




\section{List of Tables}

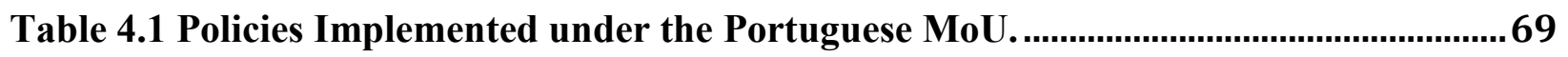

Table 4.3: Spain's response to recommendations made via the European Semester............76

\section{List of Illustrations}

Graph 3.1 - Unemployment in Selected Countries (Percentage) .............................................45

Graph 4.2: Spanish Employment by industry (thousands of employees) ................................75

Graph 4.4 Distributions of Seats in the GSEE Administrative Board....................................98 


\section{Chapter 1: Understanding Class Struggle During the Eurozone Crisis}

\section{Section 1.1: Thesis Overview:}

The European labour movement has suffered a great number of defeats since the Eurozone Crisis began in October, 2009. In response to the Crisis, the European Union (EU) and its Member States have implemented policies that prioritized economic competitiveness and investor confidence over the rights and living standards of the European working class. To that end, state institutions have successfully forced the working class to accept lower wages and greater employment insecurity in order to provide capitalists with a flexible, affordable workforce. They have also decreased corporate and state contributions to social services in order to lower the unit cost of labour. Consequently, 10 of the 18 Eurozone countries saw real wages decrease since the crisis began. In fact, not a single Eurozone country saw a wage increase of more than one percent. ${ }^{1}$ Meanwhile, the unemployment rate across the EU increased from 7.1 percent in 2007 to 12 percent in 2014, with an average youth unemployment rate that was 2.6 times higher than that of the general population. ${ }^{2}$ Institutionally, union density has decreased in every Eurozone countries. ${ }^{3}$ In Portugal, for example, unions were nearly decimated, with a fall in

\footnotetext{
${ }^{1}$ Benchmarking working Europe. Brussels: ETUI-REHS, 2013.: 50

${ }^{2}$ Heyes, Jason. "Flexicurity in crisis: European labour market policies in a time of austerity." European Journal of Industrial Relations 19, no. 1 (2013): 71-86.: 71

Time. "Eurozone Unemployment, Inflation Stable." Time. http://business.time.com/2014/02/28/eurozoneunemployment-inflation-stable/ (accessed March 21, 2014).

"Unemployment statistics." Statistics Explained. Eurostat. http://epp.eurostat.ec.europa.eu/statistics_explained/index.php/Unemployment_statistics\#Youth_ unemployment_trends (accessed March 14, 2014).

${ }^{3}$ OECD. "Trade Union Density." Trade Union Density. http://stats.oecd.org/Index.aspx?DataSetCode=UN_DEN\# (accessed April 14, 2014).
} 
private sector membership from 1.9 million to 300,000 between 2008 and 2012. ${ }^{4}$ Across the Eurozone, states have utilized a variety of policy tools to increase the flexibility of labour. The Member States have decentralized collective bargaining, have frozen or reduced public sector wages, liberalized wage indexation, lowered minimum wage, laid off public sector employees and have made cuts to welfare and pension programs. In contrast, the EU as a whole has earmarked EUR 3.89 trillion to support the economic needs of the financial industry. ${ }^{5}$

It is difficult to say how much worse it would have been for the working class had European labour organizations not taken the course of action that they did during the crisis. However, it is clear that during the response to the crisis, the interests of the working class were a secondary priority to that of capitalists for the EU and the governments of its Member States. ${ }^{6}$ Following in the tradition of Bob Jessop and Rianne Mahon, this thesis argues that such a result is a consequence of the relative power of the two classes in relation to the state institutions of each Member States and of the European Union. That is to say, the interests of the capitalist class were prioritized over the interests of workers because the capitalists have greater influence over state institutions.

This thesis holds the position that the capitalist state should be thought of as a matrix of public institutions, which gleans its legitimacy by providing favorable conditions for the societal production process and by facilitating and enforcing compromise between societal forces therein. Further, that the legitimacy of the state is tied to the mode of production upon which it was built.

\footnotetext{
${ }^{4}$ Porter, Eduardo. "Americanized Labor Policy Is Spreading in Europe." The New York Times, December 3, 2013. http://www.nytimes.com/2013/12/04/business/economy/the-americanization-ofeuropean-labor-policy.html?pagewanted $=1 \&$ \& $=0 \& a d x n n l=1 \& a d x n n l x=1395961216$ sTUoDNAvRSH0YRQUwDP2XA (accessed March 21, 2014).: 1

5 "State Aid Scoreboard 2014 Aid in the Context of the Financial and Economic Crisis." European Commission. European Union, 17 Dec. 2014. Web. 7 Apr. 2015.

$<$ http://ec.europa.eu/competition/state_aid/scoreboard/financial_economic_crisis_aid_en.html $>$.

${ }^{6}$ Horn, Laura. "Anatomy of a 'Critical Friendship': Organized Labour and the European State Formation.” Globalizations 9, no 4 (2012): 577-592: 579
} 
In the context of capitalism, both the worker and capitalist are equally entitled to pursue their self-interest and therefore, any decision made by a state in favour of one or the other cannot be made based on notions of social justice. On the contrary, these decisions are necessarily based upon relative ability of the two classes to apply pressure on the state. For that reason, this thesis assumes that in the instance of the Eurozone Crisis, the interests of capital must have been prioritized due to the capability of capital to influence the state in juxtaposition to the relative inability of labour to do so.

Following in the footsteps of Laura Horn, this thesis uses two concepts to describe the ability of either class to influence the state, each other and the production process as a whole. Institutional power refers to the power that a group garners through state or formally institutionalized mechanisms. Structural power, is the power that a group garners from its ability to disrupt the production process or apply pressure through informal means. ${ }^{7}$ Thus, the relative structural and institutional powers of capital and labour are central themes in this thesis. To further examine the notions of structural and institutional powers in the European context, the effects of the multi-scalar nature of the European industrial relations and policy making on the power of each class will be examined.

To quote Marx as paraphrased by George Ross and Andrew Martin, “people (and labour organizations) make their own history, but they do not make it just as they please... (they do so) under circumstances directly encountered, given and transmitted from the past." ${ }^{8}$ With this in mind, in order to understand industrial/class relations during the Eurozone Crisis, one must first understand how European integration and the neoliberal policy shift that began in the 1980s constructed the contemporary context of the crisis. Throughout this thesis, it is argued that the

\footnotetext{
${ }^{7}$ Horn, 2012, 580

${ }^{8}$ Ross, George, and Andrew Martin. The Brave New World of European Labour: European Trade Unions at the Millenium. Oxford, NY: Berghahn Books, 1999.: 2
} 
labour movement was in a weak state even before the crisis began and that the structural and overall power of the labour movement has actually been in decline since the mid-1970s. This thesis also holds that that the policy decisions that are made at the EU-level are having an increasingly significant impact on the industrial relations and socioeconomic policy in the EU as compared to the decisions made at the national-level, and will therefore focus on the interactions of capital and labour on the European-level.

When the crisis began to take shape in October 2009, the labour movement was overly institutionalized and had been alienated from large portions of the working class. Institutionally, labour organizations found themselves tied to a neoliberal structure, in which they were systematically disadvantaged. Furthermore, insufficient working class solidarity prevented the labour movement from being able to disrupt the production process in any more than a symbolic manner. ${ }^{9}$ In contrast, the removal of trade barriers has given the capital class high levels of mobility and the ability to force different countries to compete for investment. Consequently, while the structural power of labour decreased, that of capital simultaneously increased. Moreover, while labour did make significant ground in improving its institutional power, it simply was not able to keep pace with the rapid gains that capital made in the same regard. Thus, in the period preceding the 2008 crisis, labour in the European Union was both institutionally and structurally weak in comparison to capital. As such, over the course of the crisis the labour movement has had very little success in pushing back against the dismantling of the welfare structures or in defending the European working class.

Prior to the crisis, policy decisions at the EU took place in a structure that promoted compromise between a wide range of policy makers and civil society organizations. However,

\footnotetext{
${ }^{9}$ The notable exception being the European Transport Workers Federation, who have had a great deal of success at the European-level (Wahl, 2014: 11)
} 
since the crisis began, the EU institutions have used unprecedented coercive powers to advance market fundamentalism, austerity, labour market liberalization and other polices grounded in neoliberalism. ${ }^{10}$ This has constituted an important up-scaling ${ }^{11}$ in the European economic policy and in industrial relations. Such up-scaling was exemplified when all but four EU Member States ${ }^{12}$ signed the Fiscal Pact in March 2011. The purpose of the Fiscal Pact was to give the European Commission a greater ability to enforce cohesion of economic policy between the EU Member States. Based on the Open Method of Coordination (OMC), which allowed the EC to make recommendations to the Member States, the Pact required all signatories to formulate and implement economic policies based on the recommendations of the Commission. The Commission, which formerly had no decision making power in relation to socioeconomic and industrial relations policy, was also charged with reporting on the progress of each Member States to the European Council, along with suggested sanctions for those who were unable or unwilling to comply with its recommendations. Thus the European Council and the Commission were legitimized in applying pressure on the Member States in policy areas that traditionally lay outside of the EU competencies, such as employment and welfare policy. ${ }^{13}$ In short, the Euro Plus Pact is a tool to force less competitive countries to accept policies advocated by the Commission, which over the passed quarter century, has clearly endorsed a neoliberal policy set

\footnotetext{
${ }^{10}$ Horn, Laura. "Anatomy of a Critical Friendship?: Organized Labour and the European State Formation." Globalizations 9, no. 4 (2012): 577-592.:578

${ }^{11}$ Scale refers to the vertical relationships that exist between spaces or actors at different conceptual levels of space, for example, relationships that exist between actors based on local and transnational levels respectively (Brenner, 2009, 31-32).

${ }^{12}$ The United Kingdom, Hungary, the Czech Republic and Sweden did not sign the Euro-Plus Pact.

${ }^{13}$ Busch, Klaus. Is the Euro failing? structural problems and policy failures bringing Europe to the brink. Berlin: Friedrich-Ebert-Stiftung, Internet Policy Analysis, 2012.: 33-34
} 
that by its very nature is detrimental to the interests of labour. ${ }^{14}$ In addition, the Treaty on Stability, Coordination and Governance, signed in March 2012, gave the EU the power to discipline its Member States. This treaty enabled the Commission to fine countries if they had a national deficit, which exceeded three percent of their GDP or a national debt that exceeded 60 percent. The Treaty also requires Member States to enshrine medium-term economic objectives set by the Commission into national law and preferably into national constitutions. ${ }^{15}$

Clearly, in many respects, industrial relations and economic policies have been up-scaled to the European-level. That is to say, the policy decisions that are made at the EU-level are having an increasingly significant impact on the industrial relations and economic policy, vis-àvis decisions made at the national-level. For that reason, this thesis will focus on the interactions of capital and labour on the European-level. National case studies are examined in Chapter 4, however, they are only examined in order to demonstrate the influence of the EU over nationallevel industrial relations and socioeconomic policy. As the European Trade Union Confederation (ETUC) is the official representative of workers to the institutions of the European Union, its role in industrial relations will also be a central aspect of this study.

The theory in this thesis is outlined in Chapter 2. Chapters 3 will focus on a historical analysis that focuses on the development of the neoliberal policies since the European Trade Union Confederation (ETUC) and the Union of Industrial and Employer Confederations of Europe (UNICE) ${ }^{16}$ first met as Social Partners at the Van Duchesse meetings in 1985, until the Eurozone Crisis began in October, 2009. Chapter 3 will briefly cover the events that happened

\footnotetext{
${ }^{14}$ Busch, 2012, 34; Horn, 2012; Greenwood, 2011; European-level Labour Organization Executive 2 (2013 September 26): Personal Interview; European-level Labour Organization Executive 4 (2013, November 21): Personal Interview

15 "Six-pack? Two-pack? Fiscal compact? A short guide to the new EU fiscal governance." European Commission. http://ec.europa.eu/economy_finance/articles/governance/2012-0314_six_pack_en.htm (accessed April 14, 2014).

${ }^{16}$ Later to become BusinessEurope.
} 
before 1985, but only to provide the context for the aforementioned meeting. Chapter 4 will focus on the events that have taken place since the crisis began. Both of these chapters incorporate a historical analysis and the findings from the fieldwork I carried out in Europe between September and December 2013. The conclusion of this thesis is presented in Chapter 5 . 


\section{Section 1.2: Theoretical Foundations}

The theoretical foundation of this study is grounded in a class-based analysis. Class, in this instance, is not considered a deterministic category, but a conceptual identification that classifies individuals according to their roles in the production process. It allows for the conceptualization of interests as they relate to the societal production of value and for the inference of the objectives that either labour or capital may pursue in relation to each other and the state. While this thesis adopts the definition of a class associated with traditional Marxist thought, it holds that perceptions of identity determine the ability of either class to build and maintain solidarity. In line with the tradition started by Karl Polanyi ${ }^{17}$ and the uneven spatial development theory, this thesis holds that identity is defined and perpetuated by social constructions of space and by shared experiences. ${ }^{18}$

The work of Karl Marx ${ }^{19}$ will be used to form the foundation of the class analysis, but the work of Karl Polanyi will be used to examine how identities are formed and perpetuated within a society and how perceptions of identity influence solidarity and structural power. The work of these theorists will also be used to consider how identity politics relate to aspects of employment, nationality and social status in addition to the internal dynamics of the labour movement/working class. Polanyi will again be used to examine the relationship between the state and the working class. However, this part of the analysis will rely more heavily on state-theory provided by Rianne Mahon and the historical studies of Ellen Meiksin Wood Giovanni Arrighi. ${ }^{20}$ These

\footnotetext{
${ }^{17}$ Polanyi, Karl. The great transformation. [1st Beacon paperback ed. Boston: Beacon Press, 1944.

${ }^{18}$ Polanyi, 1944.

Patel, Rajeev. "International Agrarian Restructure and the Practical Ethics of Peasant Movement Solidarity." Journal of Asian and African Studies 41, no. 1-2 (2006): 71-93.

${ }^{19}$ Marx, Karl, and Friedrich Engels. Capital; a critique of political economy. 1867. Reprint, New York: Penguin Books, 1982.

${ }^{20}$ Mahon, Rianne. "Canadian public policy: the unequal structure of representation." The Canadian state: political economy and political power. Toronto: University of Toronto Press, 1977. 165-198.
} 
authors show that the purpose of the capitalist state is, and always has been, to manage the plurality of social interests with the objective of maximizing the societal accumulation of capital. Finally, this thesis makes use of the Uneven Spatial Development theory and the work of Neil Benner, Neil Smith, Rianne Mahon and Bob Jessop to examine the multi-scalar nature of the industrial relations in the European Union. ${ }^{21}$ This analysis will be complemented by the work of some contemporary scholars such as David Harvey, and Laura Horn. Likewise, the work of authors that follow in the footsteps of Polanyi, such as Rajeev Patel and Geraldo Otero are central to the theoretical foundations of this thesis. ${ }^{22}$

After the relationship between identity and class cohesion is examined, the focus of the chapter will shift to focus on the interaction of the two classes that take place in the confines of, and in relation to state institutions. As is common with Marxist analysis, the power of the two classes will be defined in relation to another. The abilities of each class will be measured in terms of their ability to influence the production process and the decisions of policy makers. Special attention will be paid to the power that capital gains from international mobility and the

Meiksins Wood, Ellen. "Capitalism and Human Emancipation." New Left Review 167, no. 1 (1988): 3-20. Arrighi, Giovanni. The long twentieth century: money, power, and the origins of our times. London: Verso, 1994.

${ }^{21}$ Brenner, Neil. "A Thousand Leaves: Notes on Geographies of Uneven Spatial Development." In Leviathan undone? towards a political economy of scale. Vancouver [B.C.: UBC Press, 2009. 27-50.

Smith, Neil. Uneven development: nature, capital, and the production of space. New York, NY: Blackwell, 2008.

Mahon, Rianne. "Of Scalar hierarchies and Welfare Redesign: Child Care in Four Canadian Cities." In Leviathan Undone? Towards a Political Economy of Scale. Vancouver: UBC Press, 2009. 209228.

Jessop, Bob. "Liberalism, Neoliberalism, and Urban Governance: A State-Theoretical Perspective." Eprints. University of Lancaster, 2002. Web. 25 Apr. 2015. <http://eprints.lancs.ac.uk/173/2/E2002a_antipode.pdf $>$.

${ }^{22}$ Patel, Rajeev. "International Agrarian Restructure and the Practical Ethics of Peasant Movement Solidarity." Journal of Asian and African Studies 41, no. 1-2 (2006): 71-93.

Otero, Geraldo. "Neoliberal Reform in Rural Mexico: Social Structural and Political Dimensions." Latin American Research Review 35, no. 1 (1999): 187-207. 
power that solidarity provides to the working class. Inspired by the work of Karl Polanyi, Rianne Mahon, and Asbjørn Wahl, this thesis will argue that the welfare state was created through class compromise and thus the nature and condition of the welfare state is indicative of the power of the two classes in relation to each other. ${ }^{23}$

The role of the state will then be examined in order to show the role it plays in industrial relations. The work of Ellen Meiksins Wood and Giovanni Arrighi, which describes the development of the capitalist state, will be used along with the theoretical framework laid out by Polanyi and Mahon. In line with their work, I will argue that the state has two primary functions, a) to facilitate the societal accumulation of capital and b) to manage the plurality of the society's political interests. ${ }^{24}$ This implies that the decisions of the state are not informed by moral sentiments such as justice or fairness. As members of both classes are formally equal before the law and in politics, the state logically could not make a decision that favours one group over the other. Therefore, the decisions of the state must be based in a bias which favours one class over the other. Given the state's dedication to the accumulation of capital it can be deduced that the decisions of the state are made with the goal of furthering the accumulation of capital. It is important to note that the goal is not to accumulate capital; the goal is for the state to further its legitimacy. In the current context of liberal capitalism, the accumulation of capital the means by which the state reaffirms its legitimacy in relation to society. Thus, any state bias that advantages one class over the other must be based in the socioeconomic power of the two classes, and their ability to disrupt, or apply pressure on, the societal accumulation of capital. ${ }^{25}$

\footnotetext{
${ }^{23}$ Wahl, Asbjorn. The rise and fall of the welfare state. London: Pluto Press, 2011.

${ }^{24}$ Mahon, Rianne. "Canadian public policy: the unequal structure of representation." In The Canadian state: political economy and political power. Toronto: University of Toronto Press, 1977. 165198.:168

${ }^{25}$ Marx, Karl, and Friedrich Engels. Capital; a Critique of Political Economy. 1867. Reprint, New York: Penguin Books, 1982.: 343-344
} 
To theorize about the European integration, the impact of social space on identity politics and transnational industrial relations, this thesis will rely on Neil Smith and Neil Brenner's work on Uneven Spatial Development (USD) theory. Proponents of USD argue that the way capitalism is experienced in a specific place is determined through the interactions of actors who have interests associated with the space in question. ${ }^{26}$ Space, in this context, is socially defined, and as such, definitions of space are perpetuated and influenced by the social interactions, experiences, power relations and institutions that are associated with that space. Thus, social spaces can be created, disbursed, relocated, redefined and destroyed as the nature of the social relations and shared experiences associated with that space changes and vice versa. ${ }^{27}$ USD allows us to examine the multi-scalar interaction of capital and labour, allowing us to see the advantage that capital has gained from operating on the transnational scale as opposed to labour whose representation by and large remains either on the national level or has even been decentralized to subnational levels.

To theorize about how transnational solidarity is formed and sustained, this thesis will lean on studies regarding how other social movements have manage to up-scale their efforts. In addition to vast amount of work that has been done on the European labour movements, ${ }^{28}$ the work of Marc Edelman will be used to examine the factors which enable and hinder institutional and internal class solidarity. ${ }^{29}$ Edelman's work focuses on the up-scaling of Transnational

\footnotetext{
${ }^{26}$ Mahon, Rianne. "Of Scalar hierarchies and Welfare Redesign: Child Care in Four Canadian Cities. ." In Leviathan undone? towards a political economy of scale. Vancouver [B.C.: UBC Press, 2009. 209-228.: 209-210

${ }^{27}$ Brenner, Neil. "A Thousand Leaves: Notes on Geographies of Uneven Spatial Development." In Leviathan undone? towards a political economy of scale. Vancouver [B.C.: UBC Press, 2009. 27-50.: 29-30; Smith, 2008, 175

${ }^{28}$ Bengt Larsson, 2012; Andrew Martin and George Ross, 1999; Christophe Degryse and Pierre Tilly, 2014; Justin Greenwood, 2011; Richard Balme and Didier Chabanet, 2008; and Steffen Lehndorff, 2012

${ }^{29}$ Edelman, Marc. "Transnational Organizing in Agrarian Central America: Histories, Challenges, Prospects." Journal of Agrarian Change 8, no. 2-3 (2008): 229-257.
} 
Agrarian Movements, which like labour organizations in Europe, often face problems when building transnational solidarity because of a "variety of intra-organizational problems, including political differences, disputes over resources... and second, an external political, economic and demographic environment that has become increasingly unfavorable." ${ }^{30}$ His analysis is useful as it allows us to understand how identity is constructed and how it influences class solidarity.

\footnotetext{
${ }^{30}$ Edelman, Marc. "Transnational Organizing in Agrarian Central America: Histories, Challenges,
} Prospects." Journal of Agrarian Change 8, no. 2-3 (2008): 229-257.: 229 


\section{Section 1.3: Methodology}

In the fall of 2013, I spent 97 days in Europe from September $1^{\text {st }} 2013$ to December $6^{\text {th }}$ 2013. During that time I carried out a series of semi-structured interviews with trade unionists, national- and European-level labour representatives, Members of the European Parliament (EP), staff of the European Union institutions, academics, and business peoples. In total, 29 formal interviews and two off the record interviews were completed. The interviewees were recruited through a snowball recruitment strategy. While in Europe I also attended industrial relations themed conferences organized by the Austrian Chamber of Labour, the European Trade Union Institute and the Transnational Institute. I also sat as an observer in meetings of the executive committee of Group II (Trade Unions) in the European Economic and Social Committee and in the General Assembly of the European Trade Union Confederation (ETUC).

I was able to include a wide range of participants, which included peoples from 16 different countries that were associated with 23 organizations. Participants from all three major European trade union traditions (Christian, Social Democrat, and Communist) were also represented, as were all industrial sectors, according to the classification in the European Trade Union Federation (ETUF) structure. I am bound to maintain the anonymity of the participants as per the research protocol agreed to by the Carleton University Research Ethics Board. However, the lists below provide some insight into the diversity of the participants' experiences and perspectives. A notable weakness is that there were no specific representatives of precarious workers or reproductive workers included in the study.

Participants' Countries of Origin:

Austria, Belgium, the United Kingdom, the Czech Republic, Denmark, the Netherlands, Italy, Ireland, France, Germany, Greece, Latvia, Lithuania, Poland, Portugal, Spain and Sweden. 
Organizations that were represented by Participants:

2 transitional labour organizations, 2 European-level labour organizations, 4 European industry federations, 1 transnational employer organization, 8 nationally-based trade union confederations, 2 Members of the European Parliament, 2 Academics, 5 employees in European Union institutions.

The purpose of the interviews was to use the prospective of the participants to understand the socioeconomic and political context in which the EU was constructed and which guided the policy response to the Eurozone Crisis. In addition the prospective of the interviewees were asked which factors they believed were empowering or disempowering for the labour movement. The participants were also asked to speak to the effectiveness of the labour movement on the European-level and to the various strategies that were used to engage with the EU level decisionmaking. Given the role that the ETUC has as the official representative of workers to the European Union, several questions were also designed to gage the opinions of the ETUC itself. These questions were designed to identify divisions in the labour movement and to characterize the relationships labour organizations have with other societal organizations/movements, i.e. political parties, unorganized workers, social movements and non-governmental organizations (NGOs). Finally, the participants were asked what they believed would be the best path forward for the labour movement in the EU.

The information that the participants provided in relation to the pre-crisis period is be presented in Chapter 3 and will show how the labour movement steadily moved toward institutional forms of representation while their structural forms of action steadily declined. It will also show how the various treaties of the European Union have prioritized the interests of capital over the rights of workers to effective socioeconomic security and democracy. This section will also show how the decisions of the European Court of Justice in the Laval (C341/05), Viking (C-438/05) and the Rüffert case (C-346/06) prioritized rights such as the 
freedom to provide services, freedom of establishment (Article 49 of the TFEU) and the right to provide a service or to work (Article 29 of the TFEU) over the right to bargain collectively or to strike. ${ }^{31}$

Chapter 4 will focus on the events that occurred during the Eurozone crisis itself. It will focus on how the European Union and the so-called Troika (the European Central Bank, European Commission and the International Monetary Fund) coerced countries to undergo austerity throughout the crisis. It will illustrate that while the crisis took a different form in each country, that the roots of the crisis can be traced back to the actions of financial capital under the purview of neoliberal policy. In addition, while it was the actions of capital that brought on the crisis, it was the workers that were made to bear the consequences of their actions. This chapter will go on to show that the weakness of labour is rooted in its lack of structural power. However it will also show that the labour movement, and especially the ETUC, has begun to pursue a new strategy to rebuild its structural influence. Since the mid-1990s, and increasingly over the course of the Eurozone Crisis, the ETUC et al. have attempted to cooperate with non-union social movements and organizations to construct a pan-European identify and solidarity. While it is too soon to say if such groups will be able to match the power of capital, it is clear that the structural strategies of the 1970s are no longer capable of meeting the challenge at the EU level.

\footnotetext{
31 "Consolidated Version of the Treaty on the Functioning of the European Union." Official Journal of the European Union C 326 (2012): 47-199. http://eurlex.europa.eu/resource.html?uri=cellar:ccccda77-8ac2-4a25-8e66a5827ecd3459.0010.02/DOC_1\&format=PDF (accessed April 26, 2014). Greenwood, Justin. Interest representation in the European Union. Houndmills, Basingstoke, Hampshire: Palgrave Macmillan, 2011.:111
} 


\section{Section 1.4: Conclusion}

The results from my interviews conclusively show that it is widely agreed that the European labour movement has failed in protecting the interests of labour, both before and after the Eurozone crisis took shape. In my interviews, there was only one participant who had a dissenting opinion on this matter, and he/she was a representative of an employers' organization. That particular participant pointed to the example of when the ETUC released a joint statement with BusinessEurope calling for flexicurity as an example of the ETUC successfully protecting the interests of workers and as an example of working class strength at the EU-level. ${ }^{32}$ Interestingly, other participants pointed to that same document as an example of the ETUC was failing European workers and bending to the pressure of capital. ${ }^{33}$ With the exception of the employers' represented, none of the other participants believed that the labour movement had been successful. Some even questioned the presence of the labour movement at the Europeanlevel, one participant going as far as to refer to the European labour movement as a "fantasy". ${ }^{34}$

It was also widely agreed by the interviewees that the challenges that face the labour movement developed over the past 30 years, as neoliberal principles were continually engrained into the developing structure of the European Union. While they may not have been fully implemented as soon as they were ratified, the treaties of the EU continually subjugated social interests to the interests of capital and obliged EU Member States to abide by neoliberal economic principles. This perception is further verified by the rulings of the European Court of Justice the European Union in the Laval, Viking, Luxembourg and Rüffert court cases, the monetary policy implemented by the European Central Bank, the policy instruments that were

\footnotetext{
${ }^{32}$ Transnational Employer Representative - 1 (2013, November 15): Personal Interview

${ }^{33}$ International Labour Organization Executive 1 (2013 September 27): Personal Interview; Europeanlevel Labour Organization Executive 4; MEP - 2 (2013, November 12): Personal Interview

${ }^{34}$ MEP - 2 (2013, November 12): Personal Interview
} 
introduced in response to the crisis, the coercive force that the Troika applied on the crisis countries, and of course, the flexibilization, liberalization and austerity policies implemented by the Member States themselves. The fact that the language used by the European Union to justify the policy response was so similar to the language of BusinessEurope and completely contradicted the language of the ETUC speaks to the influence that capital has in the EU in contrast to the working class.

The weakness of the labour movement is founded in its inability to influence Europeanlevel policy, insofar as they have very little hard power with which to influence the decision making process. ${ }^{35}$ As the history of the Eurozone Crisis indicates, EU level policy has major direct and indirect implications for industrial relations, the provision of public services and the overall well-being of European workers. With regards to the ETUC itself, all but the one participant agreed that it had failed in its roles as a supranational lobbying organization and as a representative of workers in the European Social Dialogue. However most agreed that this was due to the marginalization of the European Parliament and the Social Dialogue, factors that were beyond the official powers of the ETUC. Overall though, it was agreed that the ETUC helped to facilitate solidarity, simply by having trade unionists in the same room together. It was also agreed that the ETUC (perhaps conflated with the ETUI) greatly expanded the research capacity of the European Labour movement. ${ }^{36}$

The major problem faced by the movement at the European level is its inability to coordinate workers across Europe. It is so lacking in structural power that many research participants reported that neither EU institutions nor employer organizations respect organized

\footnotetext{
${ }^{35}$ Greenwood, 2011, 122

${ }^{36}$ European-Level Executive - 1 (2013, September 27): Personal Interview; National Representative 1 (2013, October 30): Personal Interview; National Labour Representative 1(2013, October 30): Personal Interview
} 
labour. One international labour executive said "the elites do not fear the trade unions anymore, they are glad as long as the unions are stuck begging for a seat at the table. ${ }^{37}$ This quotation speaks to the fact that many believe that organized labour is being pushed out of the policy discussion in Brussels. In order to push its way back into those discussions, the labour movement would have to be able to apply sustained pressure on the capitalist class and on political decision makers. The degree to which it will be able to do so will dependent on its ability to engage and mobilize the working class. This will require labour organizations to immerse themselves into a wider, working class movement that would ideally include unorganized workers, the unemployed, young people, students and others who are traditional excluded from labour struggles. However, the working class remains divided by identities that are built on differentiating experiences related to nationality, sector of employment, ethnicity, gender, status of employment and age. In order to operate effectively on a European scale, perceptions of identity will have to be reimagined to incorporate European scale identities based on the shared experiences of workers across the EU.

To conclude, over the course of the crisis the European working class has experienced far more defeats than victories. These defeats have come in the form of decreased political influence, losses in wages, pensions and other benefits and the reduction or public services. The movement has been weakened by its dependence on institutional representation, which has entrenched divisions between union executives and ordinary members, as well as divisions based on identities within the working class. There is clearly a need for the movement to up-scale its efforts in order to operate on the request scale to meet the attack of capital on the European-level. This will mean building a labour movement with a collective identity based on the common experience of European workers. There are signs of hope, but capital clearly has the upper hand.

\footnotetext{
${ }^{37}$ International Executive - 1 (2013, September 27): Personal Interview
} 


\section{Chapter 2: Theorizing European Industrial and Class Relations}

\section{Section 2.1: Chapter Introduction}

This chapter provides the conceptual foundation of this thesis. In what follows, Section 2.2 engages with the concept of class and places it as the point of departure for this project. This section also provides the concepts of structural and institutional power as conceptual tools that can be used to articulate the relative power of the capitalist and working classes. Thereafter, Section 2.3 briefly contextualizes the historical development of the capitalist state and its role in facilitating industrial/class relations. In addition, this section relies on the work of Polanyi, Jessop and Mahon to speak to the role of the state both in the general terms of the capitalist mode of production and within the neoliberal paradigm. Finally, Section 2.4 uses Uneven Spatial Development Theory to examine the link between identity, solidarity and the power of the working class.

This chapter ultimately concludes that across the advanced capitalist world, organized labour has lost significant influence in relation to capital. Moreover, that in order to be able to challenge the structural power of capital, the labour movement will need to build international alliances between labour organizations, with new social movements and existing civil society organizations. Ultimately, the goal will be to build broad based solidarity and to challenge the legitimacy of the state and the mode of production. This will depend greatly on the ability of the working class to articulate and champion an alternative to the neoliberal paradigm. 


\section{Section 2.2: Class formation and Industrial Relations}

The struggle between the working and capitalist classes is the central concept in industrial relations. The conception of class in this sense cannot be thought of as a deterministic classification; it is an analytical category which speaks to the role one holds in the production process. It is through the lens of a class-based analysis that one can build an understanding of the common socioeconomic and political interests of different social actors and groups, and that the interaction of social forces, the interests of organized labour, of capital, and the role of the state in international, advanced capitalist society can be understood. ${ }^{38}$ Plenty of other aspects of one's identity such as gender, ethnicity, nationality and terms of employment also influence one's social interests. However, as this project is primarily focused on studying contemporary industrial relations, class-based theory is the most appropriate point of departure for this study.

As originally noted by Karl Marx, the struggle between the capitalist and working classes is defining feature of the capitalist mode of production. The working class is made up of all those who sell their labour for a wage. In contrast, the capitalist class controls the means of production and earns profits by exploiting the working class. Suffice it to say, it is in the interests of the worker to garner as much security from of his/her labour as possible. In contrast, it is in the interest of the capitalist to suppress the compensation for the productive and reproductive work of laborers in order to increase profits and accumulate capital. Thus, the economic interests of the worker and capitalist are adversely related. ${ }^{39}$

\footnotetext{
${ }^{38}$ Rianne Mahon describes all 'advanced capitalist societies' as having five common characteristics, their working class is well organized and the vast majority of it is employed in the formal economy, there are a plurality of capitalist interests present in the society, the state intervenes significantly in the economy, the power of the state is concentrated in a state executive, the government is supported by a permanent, professional bureaucracy. (Mahon, 1977, 166)

${ }^{39}$ Marx, Karl, and Friedrich Engels. Capital; a Critique of Political Economy. 1867. Reprint, New York: Penguin Books, 1982.:375
} 
It is well documented that an individual's political and social interests are undeniably linked to his/her economic interests. Socially, an individual's community status, the neighborhood he/she lives in, his/her education, social groups, health, and recreation are inexorably linked to their income and economic security. Likewise, one's ability to influence public policy and electoral politics is also closely tied to their wealth and their ability to influence the production process. Therefore, the social and political interests of anyone engaged in the capitalist mode of production is to a large extent, tied to their role in the production process and thus to the struggle between the classes. ${ }^{40}$ As both the capitalist and worker are equally justified in pursuing their own interests, and as both are formally equal before the law and in politics, it is impossible for any unbiased political or judicial institution to make a decision in favour of one over the other. Instead any decision made by state institutions regarding the interactions of capital and labour cannot be based on conceptions of moral sentiment such as fairness or justice, but on biases that are indicative of the relative influence and power of one class in relation to the other. As stated by Marx, "[t]here is here therefore an antinomy, of right against right, both equally bearing the seal of the law of exchange. Between equal rights, force decides. ${ }^{, 41}$ Thus, the state can do little more than reproduce socioeconomic power relations that are prominent elsewhere in society. This is exemplified in the work of Mahon below:

"(The state is a) relation, an expression of the antagonistic and contradictory relations among classes and fractions: it does not possess power ('the state is not a subject'). The structure of the state is nothing but the mediated expression of basic socioeconomic inequalities as these are manifested politically, in the various forms and levels which the class struggle assumes at a particular point in time in a given society... This means that the state, in its concrete, institutional manifestation, does not

\footnotetext{
${ }^{40}$ Marx, Karl, and Friedrich Engels. Capital; a critique of political economy. 1867. Reprint, New York:

${ }^{41}$ Ibid, 344 Penguin Books, 1982.: 343-344
} 
constitute a simple homogeneous unit [and] is destined to reproduce class

divisions... [and] by virtue of its very structure is divided". 42

Laura Horn differentiates the two different, interconnected avenues through which labour gains power, or force, and the ability to struggle against capital through and outside the state. The first, structural labour power, is derived from the role labour plays in the production process and their capacity to disrupt it. The second Horn describes as the power that is garnered from their ability to act through institutionalized or state-run forms of representation. ${ }^{43}$ For the purposes of this project this type of power will be referred to as institutional power. As the power of the working class can only be described in relation to that of capital, it logical to describe the power of capital on the same bi-dimensional framework. Thinking of power in these terms is useful when articulating the nature of class struggle, however before moving to that topic, the role and nature of the state in a capitalist mode of production should be reviewed.

\footnotetext{
${ }^{42}$ Mahon, 1977: 170

${ }^{43}$ Horn, Laura. "Anatomy of a Critical Friendship: Organized Labour and the European State Formation." Globalizations 9, no. 4 (2012): 577-592.: 581
} 


\section{Section 2.3: Capitalism, Liberalism, Class Relations and State Theory}

According to Rianne Mahon, the legitimacy of any state is tied directly to the mode of production upon which it was built. ${ }^{44}$ In 1988, Ellen Meiksins Wood contrasted state-society relations during feudal and capitalist time periods. In the feudal era, the aristocratic class used the political and judicial powers of the state to serve their own interests and exploit the rest of society. In that era, the state was to the aristocrats what the modern corporation is to capitalists; an institution that enabled the exploitation of the subaltern classes and that represented the interests of the hegemon. ${ }^{45}$ It represented the interests of the aristocrats and through the aristocracy it gained subjectivity. This fact is exemplified by the famous quote by King Louis XIV who in 1755 stated before the Parisian Parliament "L'Etat c'est moi" (The state, it is I - or The state, it is mine). ${ }^{46}$

A powerful capitalist class began to take shape towards the end of the feudal era. In The Long Twentieth Century (2010), Giovanni Arrighi notes how the relationship between the capitalists, corporations and the state was originally complementary. Private banks established a financial system, corporations were established to build infrastructure and to build and maintain colonies. New corporate institutions played a major role in establishing the European empires around the world and accumulated tremendous amounts of wealth for their owners and their sovereigns. The aristocrats, through the state, dedicated the resources and military force needed to support the ventures of the corporations and ensure their economic viability. They also lent to

\footnotetext{
${ }^{44}$ Mahon, Rianne. "Canadian public policy: the unequal structure of representation." In The Canadian state: political economy and political power. Toronto: University of Toronto Press, 1977. 165198.

${ }^{45}$ Meiksins Wood, Ellen. "Capitalism and Human Emancipation." New Left Review 167, no. 1 (1988): 320.: 9

${ }^{46}$ Rowen, Herbert. 'L'Etat c'est a moi: Louis XIV and the State.” French Historical Studies 2, no. 1. (1961): 83-98: 83
} 
them the legitimacy of the sovereign, which came in useful when dealing with the other subaltern classes and with their counterparts from other countries. ${ }^{47}$

As capitalist production expanded in Europe and throughout the world, the capitalist class grew stronger, and the relations of production shifted away from the aristocrat-peasant binary to that of the capitalist-proletariat. A contradiction developed between the role of the state and the shifting mode of production and the legitimacy of aristocratic rule began to deteriorate. As the mid- $19^{\text {th }}$ century approached the subaltern classes (including the capitalists) grew wary of exploitation at the hands of the aristocrats and rose up in revolution across Europe. ${ }^{48}$ The aristocrats were forced to surrender the power of the state and the feudal state was re-fashioned on capitalist mode of production. The capitalist state maintained its character as an institutionalized form of political, legislative and judicial societal power. However, in order to prevent feudal exploitation, clear limits were put on political and judicial power. These limitations grew overtime to the point where all citizens were given formal equality in politics and before the law. The state also retained its function in supporting societal production. Just as the feudal state supported serfdom, supporting capital accumulation became a primary function of the state. ${ }^{49}$

In theoretical terms this represented an important transformation of the state. In capitalism, the state no longer represented the political and judicial interests of any specific class. Official equality transformed the state from the institutionalized form of political and judicial exploitation, to the institutionalized arrangement of societal interactions in the judicial and political arenas. As the state no longer represented the interests of any given class, it could no

\footnotetext{
${ }^{47}$ Arrighi, Giovanni. The long twentieth century: money, power, and the origins of our times. London: Verso, 1994.: 87 et seq.

${ }^{48}$ As well as in parts of Latin America

${ }^{49}$ Meiksins Wood, 1988, 9; Mahon, 1977, 168
} 
longer be described as an actor sui generis. Instead the state must be thought of as an institutionalized matrix of societal political relationships, in which the plurality of social interests is represented. Though, the state is more than an institutionalized arena for political interaction, it also has the power to enforce compromise on society. It gains the ability to do so through its right to legislate and enforce law, its monopoly of legitimate coercion, and the legitimacy gained from its perceived neutrality by other social groups. ${ }^{50}$ One of its more significant functions in industrial relations is being able to force each class to accept such compromises and thus minimize disruptions in the production process.

Following World War Two, capitalism in the West was grounded in Keynesian economic theory, which aimed to facilitate the accumulation of capital by using public policy to develop and support the domestic market. On the supply-side the state used protectionist policies to shelter their capitalist class from international competition. For the demand-side of the equation, state governments enacted policies that were designed to maintain high levels of employment and increase the spending power of the working class. ${ }^{51}$ According to Bob Jessop, the neoliberal policy shift emerged as the Keynesian policy set struggled to facilitate the continued accumulation of capital in the advanced capitalist world (reviewed in Chapter 3). Western capitalists had begun to upscale their operations to the international level and the protectionist policies advocated by Keynesianism were impeding their progress. ${ }^{52}$

According to Jessop, neoliberal ideology is founded on the political, economic and social principles of classical liberal. Socially, the aim of a neoliberal policy set should be to maximize

\footnotetext{
${ }^{50}$ Polanyi, Karl. The Great Transformation. 1st Beacon paperback ed. Boston: Beacon Press, 1944.: 21

${ }^{51}$ Waddington, Jeremy, and Reiner Hoffmann. "Reform, Organizing and Restructuring." Trade unions in Europe: Meeting the Challenge. Brussels: P.I.E - Peter Lang, 2003. 33-63: 33

52 Jessop, Bob. "Liberalism, Neoliberalism, and Urban Governance: A State-Theoretical Perspective." Eprints. University of Lancaster, 2002. Web. 25 Apr. 2015. <http://eprints.lancs.ac.uk/173/2/E2002a_antipode.pdf $>: 2$
} 
freedom between formal between citizens. Freedom in the liberal sense is maximized through the free market, which provides producers, workers and consumers with the greatest number of options and thus freedom. ${ }^{53}$ In Keynesianism, the role of the state was to mitigate the social risks of economic imbalances in the market place. In contrast, as Polanyi points out, liberal discourse describes state intervention of this nature as inefficient at best and at worse, as an attack on economic and thus social freedoms. ${ }^{54}$ According to Jessop, the role of the state in neoliberalism is to support and further the expansion of market place, and in doing so, advance the freedoms of society. ${ }^{55}$

To that end, neoliberal ideology calls for the state to continue to protect private property, use public policy to create favorable conditions for investment, and importantly remove protectionist policies and facilitate the continued up scaling of production to the international level. ${ }^{56}$ During the Keynesian era, protectionist policies tied the production process to the nationstate level. As such, the ability of organized labour to disrupt the production process with work action provided unions with considerable structural power. However, the removal of trade barriers and the liberalization of financial markets have provided capital with increasing transnational mobility; the ability to relocate to districts that provide the most conducive conditions for capital accumulation. Institutionally, most labour organizations are still tied to the nation-state level and have, for the most part, yet to build sufficient transitional solidarity with their counterparts in other regions. Accordingly, they have been forced to lower expectations in order to complete with bids workers in other parts of the world. States too have now been forced into competition for investment. In this context, welfare programs and social spending have been

\footnotetext{
${ }^{53}$ Jessop, 2002, 2

${ }^{54}$ Polanyi, 1944, 37

${ }^{55}$ Jessop, 2002, 5

${ }^{56}$ Jessop, 20027
} 
contextualized in the international market place as a cost of production. In a phenomenon commonly referred to as 'social dumping', state-governments have been forced to lower corporate taxes and the social responsibility of production in order to attract investment. ${ }^{57}$

With regards to industrial relations, most advanced capitalist societies have seen the state move to institutionalize industrial/class relations and thus class conflict. This has had had a major impact on the nature of class conflict throughout Europe and across the world. As noted by Polanyi, the institutionalization of industrial relations has greatly reduces instances of work action and interclass physical violence. ${ }^{58}$ While it is difficult to argue that the reduction of violence is undesirable, reduced work action has impeded the development of the working class solidarity. As noted by Donald Swarts and Rosemary Warskett, strikes and work action build solidarity and is when organized labour is most visible to the wider community. The run up to a strike is often the only time that members attend union meetings and take part in a picket line is perhaps the most tangible form of resistance that a typical worker may experience in his/her lifetime. ${ }^{59}$ With the institutionalization of the labour movement, sectionalism also became entrenched in the structure of representation. Sectionalism refers to the tendency of workers to organize based upon their trade or industry of employment, often to the exclusion of other workers. ${ }^{60}$ Likewise, unorganized, the unemployed, reproductive, and/or precarious workers, have all by and large been excluded from what is traditionally referred to as the 'labour movement'. Horn argues that when a movement becomes overly institutionalized and dependent on the state apparatus, they become vulnerable to shifts in the political and socioeconomic

\footnotetext{
${ }^{57}$ Jessop, 2002, 3

${ }^{58}$ Ibid, 21

${ }^{59}$ Swartz, Donald, and Rosemary Warskett. "Canadian Labour and the Crisis of Solidarity." In Rethinking the politics of labour in Canada. Halifax, N.S.: Fernwood Pub., 2012. 1-22.: 4

${ }^{60}$ Swartz \& Warskett, 2011: 6
} 
landscape ${ }^{61}$ Moreover, that increased institutionalization leads to the professionalization of the labour movement and the alienation of every day workers from their representatives. Grassroots mobilizations have been gradually replaced by closed-door negotiations and economic analysis. Instead of being represented by their coworkers, workers were represented by lawyers, economists, policy experts, professional negotiators and researchers. Thus, labour union executives lose contact with their membership and in consequence the structural power of the movement is diminished. ${ }^{62}$

The historical evolution of the labour movement has centralized the organization of workers at the state level and according to sector of employment. These factors have all obstructed working class solidarity and thus limited the ability of the class to affect the production process in a meaningful way. ${ }^{63}$ Simultaneously, neoliberal policies have increased the mobility of capital which has dramatically increased the ability of capital to influence production. Moreover, as the structural strategies of the labour movement lost effect, they began to turn to institutional forms of representation to forward the interests of the working class. However, in doing so, they became complacent in the neoliberal policy shift. That is to say, that their goal of organized labour is rarely to provide an alternative to neoliberalism, it is often just to make neoliberalism viable in the medium-term for the working class. ${ }^{64}$ Moreover, through the proliferation of mutual funds and the investment of pensions into stocks and bonds, the interests of the working class also became tied to that of the financial sector. ${ }^{65}$ Consequently the working

\footnotetext{
${ }^{61}$ Horn, 2012, 581

${ }^{62}$ Ibid, 581

${ }^{63}$ Ibid, 584; Swartz and Warskett, 2012, 9

${ }^{64}$ Jessop, 2002, 6; European-level Labour Organization Executive 1 (2013 September 26): Personal Interview; International Labour Organization Executive 1 (2013 September 27): Personal Interview

${ }^{65}$ Panitch, Leo and Sam Gindin. "The Current Crisis: A Socialist Perspective." Studies in Political Economy 83 (2009): 7-31.:17
} 
class tends to conflate the interests of the financial capital with their own, and has made labour organizations hesitant to infringe upon the profitability of the financial sector. ${ }^{66}$

The state provides benefits to capital as much as it is necessary to appease capital to the point that they will remain invested in the state's social economy. Likewise the state provides social services and supports labour interests insofar as it is needed to maintain a capable and relatively complacent workforce that can meet the demands of production. ${ }^{67}$ The primary objective of the state is to maintain its legitimacy, which is primarily accomplished by stewarding the societal accumulation of capital. In theoretical terms then, in order for the working class to reverse austerity and, protect wages, restore economic security and/or improve working conditions they will have to threaten the interconnected legitimacy of the and production process and develop an alternative that comes to be regarded as 'more legitimate' than the neoliberal paradigm. ${ }^{68}$

In order to be able to challenge the structural power of capital, the labour movement will need to construct and sustain broad based solidarity throughout the working class. This will likely require the formulation of transnational alliances between labour organizations, with unorganized workers and non-labour civil society organizations. In the final section of this chapter, the ways in which identity influences solidarity in the working class is examined. It will also focus on how identity is built on perceptions of space and on shared experiences. It will then turn to theorize on how a pan-European worker identity might be formed.

\footnotetext{
${ }^{66}$ Panitch \& Gindin, 2009, 17

${ }^{67}$ Mahon, Rianne. "Of Scalar hierarchies and Welfare Redesign: Child Care in Four Canadian Cities." In Leviathan Undone? Towards a Political Economy of Scale. Vancouver: UBC Press, 2009. 209228.: 209

${ }^{68}$ Horn, 2012, 582
} 


\section{Section 2.4: Identity and Working Class Solidarity}

Contrary to mainstream political economy, which describes global capitalism as being exerted by a central core onto a hapless periphery, Uneven Spatial Development (USD) theory holds that the way capitalism is experienced in a specific place is characterized through the interactions of social actors that operate in a multi-scalar societal network. The first thing that needs to be understood in USD is that the concept of 'social space' and how it differs from 'natural space'. When one speaks about a 'natural space' the reference is to a demarcated, geographical location; social space goes beyond aspects of physicality to include the social structures and relations through which space is conceptualized, assigned meeting and ultimately defined. Just as societal structures and relationships are often multidimensional, social spaces on many different societally defined scales. For example, a specific local could be defined as a neighborhood, an industrial area, as being urban, and in defined in relation to its municipal, subnational and state jurisdiction. ${ }^{69}$ Space in this sense is socially determined and as such, expressions of space (i.e. ownership, territoriality, urban) perpetuate and influence perceptions of identity (i.e. home owner, nationality, urbanite) and vice versa. What all these expressions of identity and space have in common is that they are established through human interaction and they all enable groups to define and assign meaning to space and its inhibitors. Furthermore, they influence the ways in which individuals interact with socially constructed institutions such as states, unions, interest groups, transnational organizations, intergovernmental organizations, families, spiritual institutions, corporations and interest groups and ultimately how one engages with society and the production process.

\footnotetext{
${ }^{69}$ Brenner, Neil. "A Thousand Leaves: Notes on Geographies of Uneven Spatial Development." In Leviathan undone? towards a political economy of scale. Vancouver [B.C.: UBC Press, 2009. 2750.: 33
} 
The way capitalism is experienced in a specific place is not just shaped at the transnational level, but also by locally based institutions, social networks, histories and peoples. ${ }^{70}$ This is not to say that a local community is capable of completely thwarting the development of capitalism. As noted by David Harvey, callous violence has been used commonly throughout history in order to impose capitalism on an unwilling or resistant population. ${ }^{71}$ However, the relative positionality of a space (and those who occupy it) in relation to other spaces greatly influences capacity of its occupants to influence how capitalism is experienced. The structural power that capital gains from increased mobility is garnered from the ability to influence the character of social production in a constantly expanding number of spaces. Moreover, workers have been forced to compete with their counterparts on national and subnational scales, which has compromised the positionality of the workers located in these spaces. Moreover, the institutionalization of organized labour has also largely limited the workers to organizing on the national scale, hindering their ability to operate on the transnational scale/level.

The idea of space and identity being mutually reinforcing is important to the labour movement. As noted by Patel, neoliberal capitalism has affected workers in different sectors and places in different ways. The differences among the experiences of these workers were influenced by the differences that existed between the locally based histories and peoples. Identities were built upon these experiences, and upon these identities, solidarity was constructed and extended insofar as the logic of the perceived identities permitted. In relation to work, sectionalism, regionalism, language and nationalism thwarted any sustained solidarity between workers at the transnational level. ${ }^{72}$

\footnotetext{
${ }^{70}$ Mahan, 2009, 209-210

${ }^{71}$ Harvey, David. The Limits to Capital. New York: Verso. 2006.: 373

72 European-level Labour Organization Representative - 2 (2013, November 12), Personal Interview; MEP - 2 (2013, November 12), Personal Interview
} 
Identities of the domestically defined worker need to be challenged in favour of the identity of the transnational worker. This identity will allow for solidarity to be built on the requested scale to challenge transnational capitalism. Likewise, identities tied to places of employment and the related social status should also be challenged in a similar manner. This includes identities that are related to being unemployed, an unorganized labourer, a student, or a stay-at-home parents/care giver. The common identity will have to be built on the shared experiences that workers have with capital, such as those listed above. In order to build such an identity, resistance will have to be focused on issues that are problematic for as much of the transnational working class as possible. 


\section{Chapter 3: The Construction of the EU, the Neoliberal Foundation and the Class Relations Therein.}

\section{Section 3.1: Chapter Introduction}

Chapter 2 provided a theoretical foundation that allowed for the conceptualization of class/industrial relations, the development of the capitalist state and the neoliberal paradigm and the nature of multiscalar class construction. The purpose of Chapter 3 is to provide a historical account of how these factors were realized in the context of Europe during the neoliberal policy shift and during the construction of the European Union. Throughout my interviews, labour representatives unanimously agreed that organized labour had not been sufficiently successful in forwarding the interests of workers during the Eurozone Crisis. This point of view is well documented in the excerpt below, which was taken from an interview with a European-level labour organization executive.

We have not been successful at all in terms of defending, limiting or stopping this pressure on wages. We are not successful, we are not successful enough, at pushing for a growth approach... when you speak of our efficiency, it is very mixed and far away from what we expect. ${ }^{73}$

In the years previous to the Crisis, the propagation of neoliberal policies and the European integration caused the production process to be up-scaled to a level and in such a way that the structural power of capital increased while that of labour declined simultaneously. The aforementioned executive believed that in those years, the labour movement, and specifically the ETUC had considerable success in building institutional capacity within the structure of the

\footnotetext{
${ }^{73}$ European-level Labour Organization Executive 1 (2013, September 26): Personal Interview
} 
European Union. ${ }^{74}$ However, labour was in a position of structural weakness and disadvantage in relation to capital during the Eurozone crisis. In consequence, European workers were the ones who ended up bearing the burden of the crisis and its aftermath.

During the crisis, the hard fought victories that labour had accomplished over the previous years were clawed back through initiatives that began at the European-level and were operationalized by the Member States. From the prospective of one Member of the European Parliament, while this was happening, policy makers all but ignored the opposition of the working class that came through institutional forms of representation on which organized labour had come to depend upon. ${ }^{75}$ As the following paragraphs will show, it is clear that the labour movement was at a disadvantage before the crisis began. Even in the years running up to the crisis, the institutions of the European Union had prioritized market freedoms over the traditional rights of organized labour.

The experience of the labour movement over the course of the crisis was a continuation of the experiences it had during the previous quarter century with European integration and the neoliberal policy shift. The purpose of this chapter is to review that experience with the aim of contextualizing the industrial/class relations when the crisis began. As stated by Laura Horn, "Trade unions need to be analyzed not merely reactive to changing forms of state, which would in effect come down to analytically reducing labour to an object, rather than subject of social struggles, but rather as attributed with agency, and complicit in structuring these social relations. ${ }^{, 76}$ With that in mind, below we examine the creation of the European Union the role of

\footnotetext{
${ }^{74}$ European-level Labour Organization Executive 1 (2013 September 26): Personal Interview; International Labour Organization Representative 3 (2013 November 22): Personal Interview ${ }^{75}$ MEP 2 (2013 November 12): Personal Interview

${ }^{76}$ Horn, Laura. “Anatomy of a 'Critical Friendship': Organized Labour and the European State Formation.” Globalizations 9, no 4 (2012): 577-592: 580
} 
organized labour therein and the influence that the EU and its neoliberal policy set has had on European industrial/class relations. 


\section{Section 3.2: The Golden Age and the New Push for Integration}

In the thirty years that followed World War Two, Keynesian economic theory dominated public policy in the advanced capitalist world. These thirty years were commonly referred to as the 'Golden Age', and were characterized by three decades nearly uninterrupted growth. During this time period, national trade and financial policy was designed to protect national markets, to limit capital flight and maintain high levels of employment. Manufacturing in this time period took place in large factories, which allowed labour organizations to find large groups of workers with similar interests, which allowed for worker solidarity to flourish. Moreover, state governments utilized protectionist policies to shelter their national industries, meaning that workers did not have to compete with their counterparts in other countries. These factors allowed the working class to disrupt the production process with relative ease. ${ }^{77}$

In comparison to today, labour organizations had a great deal of structural power during the Golden Age. The ability of unions to strike or to take work action and disrupt the societal accumulation of capital obliged both capitalists and state institutions to cooperate with labour. ${ }^{78}$ Not surprisingly then, the structural might of labour was the foundation of their strategies during this time period. Given the nation-based nature of production, most labour organizations did not have much incentive to up-scale their operations. ${ }^{79}$ There were notable exceptions though, due to historical and structural reasons that are reviewed later, workers in many sectors had already managed to develop significant transnational influence. In particular, the International Miners' Federation, the International Transport Workers' Federation and the International Metalworkers'

\footnotetext{
${ }^{77}$ Waddington, Jeremy, and Reiner Hoffmann. "Reform, Organizing and Restructuring." Trade unions in Europe: Meeting the Challenge. Brussels: P.I.E - Peter Lang, 2003. 33-63: 33

${ }^{78}$ Bernd, B and F. Traxler. (2011). Labour Relations, Economic Governance and the crisis: turning the tide again? Labour History 52(1). 1-22: 3

${ }^{79}$ Ross, George, and Andrew Martin. The Brave New World of European Labour: European Trade Unions at the Millennium. Oxford, NY: Berghahn Books, 1999.: 7
} 
Federation had been operating since the nineteenth century and had had already developed significant transnational structural power. ${ }^{80}$

As of 1950, France has fought three major conflicts with Germany and its predecessors. In 1950, French Foreign Minister Robert Schuman sought to establish a common market for steel and coal across Western Europe in order to limit the possibility of another catastrophic war breaking out across the continent. Schuman's efforts resulted in the signing of the Treaty of Paris in 1952, which created the European Coal and Steel Community (ECSC) between West Germany, France, Luxembourg, the Netherlands, Belgium and Italy. Two years after that, the coal and steel industry in Western Continental Europe was effectively transnationalized when nearly all the trade barriers related to these sectors were removed between the Treaty's signatories. ${ }^{81}$ In 1957, the same signatories signed the Treaty of Rome and built on the concept of a signal market. This Treaty created the European Economic Community (ECC) and would guarantee the free movement of people, goods, services and capital amongst its members. ${ }^{82}$

The push for European integration created a new set of political institutions that would change the nature of European industrial/class relations. The Treaty of Rome provided the EEC and its Commission with a broad range of objectives on issues related to social welfare and industrial relations. However, the EEC Commission had very little binding power and therefore neither capital nor labour made serious efforts to upscale their strategies in order to meet the EEC on the European level. In contrast, the institutions of the ECSC had the authority to oblige

\footnotetext{
${ }^{80}$ Degryse, Christophe, and Pierre Tilly. 1973-2013: 40 years of history of the European Trade Union Confederation. Brussels: ETUI, 2013: 33

${ }^{81}$ European Coal and Steel Community (ECSC) | European organization. (2014, May 25). Retrieved January 28, 2015, from http://www.britannica.com/EBchecked/topic/196004/European-Coal-andSteel-Community-ECSC

${ }^{82}$ Treaty establishing the European Economic Community, EEC Treaty - original text. (2010, October 15). Retrieved January 29, 2015, from http://europa.eu/legislation_summaries/institutional_affairs/treaties/treaties_eec_en.htm
} 
its Member States to adopt policies related to the modernization of industry, to curtail production and even to improve working conditions or increase abnormally low wages. ${ }^{83}$ Consequently, the only industrial relations were only truly up-scaled in industries related to coal, steel and transportation. Hence the relative structural power of the International Miners' Federation, the International Transport Workers' Federation and the International Metalworkers' Federation at the European-level. The EEC did cause some social dumping to take place, but the post-war recovery still provided plenty of room for growth for all national industries and all of the Member States were operating at near-full employment. ${ }^{84}$ Thus, labour organizations in other sectors still had relatively little incentive to up-scale their efforts.

Industrial relations were fairly consistent throughout the 1960s. Industry continued to grow and the EEC hosted several 'cross-industry advisory committees' with representatives of Member States, employers' and workers' organizations. Few tangible results ever came from these committees and they never really addressed industrial relations per se. Rather, these committees worked on issues such as the harmonization of vocational training and the free movement of workers. ${ }^{85}$ In 1972, the political leaders of Europe renewed efforts to integrate the European economy. In the 1972 Heads of State and Government Meeting in Paris, the Member States asked the Commission to create the Social Partners Office, which was to be in operation no later than 1974. The aim of this office was to increase communication between the various European-level labour organizations, the Union of Industrial and Employer Confederations of

\footnotetext{
${ }^{83}$ Treaty establishing the European Coal and Steel Community, ECSC Treaty. (2014, October 15). Retrieved January 29, 2015, from http://europa.eu/legislation_summaries/institutional_affairs/treaties/treaties_ecsc_en.htm ${ }^{84}$ Degryse and Tilly, 2014, 33

${ }^{85}$ Degryse and Tilly, 2014, 94
} 
Europe (UNICE) and the EEC ${ }^{86}$ It would also aim to facilitate policy learning in social policy areas for the Member States. Though this office did not have any binding power, the creation of the office was significant in that it gave the Commission an avenue to speak to states, employers and unions on issues related to labour and social policy for the first time. It was also the first time that the Heads of State sought to institutionalize an all-purpose office dedicated to industrial relations at a supranational level. The establishment of this office, along with the expansion of the EEC to include the United Kingdom, Denmark, Greece and Ireland, seemed to signal that the EEC would soon come to play a more prominent role in industrial/class relations and in social policy more broadly. ${ }^{87}$ However, as reviewed below, the dissolution of the Bretton Woods Monetary System and the 1970s oil shocks would cause turmoil and squeeze profits across the advanced capitalist world. In this context, hostility between the two classes was intensified and cooperation at the European-level proved to be difficult. Before examining how this came to influence industrial relations, we first turn more directly to examine the creation of the European Trade Union Confederation (ETUC), which became the most prominent multinational labour confederation on the continent.

\footnotetext{
${ }^{86}$ In contrast to the labour movement, which had not yet formed a single European-level organization, UNICE was established in 1958, a year after the Treaty of Rome was signed.

${ }^{87}$ Degryse and Tilly, 2013,17; European-level Labour Organization Executive 1 (2013, September 26): Personal Interview
} 


\section{Section 3.3: The Creation of the ETUC}

By the time the Social Partners Office was established, labour organizations across the continent had already formed several international confederations that were founded upon their or shaped according to their respective ideologies. The largest of these organizations was the European Confederation of Free Trade Unions (ECFTU), which consisted primarily of social democratic and moderate socialist unions. The International Confederation of Christian Trade Unions (EO-CISC) and the World Federation of Trade Unions (WFTU) - which represented Christian and Communist trade unions respectively - were also large and had members in every EEC Member State. ${ }^{88}$ In principle, the objective of the confederations was to build solidarity and move towards an international labour movement. In practice, significant logistical and political barriers prevented these organizations from having much influence on political or socioeconomic matters. It is worth noting that in the context of the Cold War, ideological barriers played a major role in limiting cooperation between the WFTU and its counterparts. However, the ECFTU and the EO-CISC also competed to be recognized as the legitimate representative of labour at the European-level by the EEC, labour organization, Member State governments and even by employers' organizations. ${ }^{89}$

Internally, the confederations were limited by many nation-based member organizations, who were concerned that up-scaling industrial and class relations could lessen their relevancy, making them redundant. ${ }^{90}$ Moreover, European-level policy still seemed to be grounded in decision-making that was made by national policy makers. Thus, most labour organizations preferred to dedicate their resources to national-level efforts, and usually preferred to lobby their

\footnotetext{
${ }^{88}$ Degryse and Tilly, 2013, 11

${ }^{89}$ Larsson, Bengt. "Obstacles to transnational trade union cooperation in Europe-results from a European survey." Industrial Relations Journal 43, no. 2 (2012): 152-170.: 155

${ }^{90}$ Larsson, 2012, 161
} 
respective national representatives on issues regarding the EEC. ${ }^{91}$ Consequently, the role of the confederations seemed to be limited to facilitating communication and information sharing amongst their membership.

In spite of having multiple European-level organizations, the Member States were committed to selecting a single organization to represent the interests of labour in the Social Partners Office. Any doubt about which organization would be chosen was quashed in 1973, when the ECFTU scored a major victory and inducted significant organizations from the all three new EEC countries, the United Kingdom, Greece and Denmark, into its ranks. The ECFTU then rebranded itself as the European Trade Union Confederation (ETUC), possibly to move away from the ideological predisposition associated with the name European Confederation of Free Trade Unions, so that the EO-CISC could join in the following year. ${ }^{92}$ The ETUC and the WFTU were now the only two major European-level organizations left, and in the context of the Cold War, the Commission was clearly against selecting a Communist organization to represent labour. Thus, the ETUC was chosen to represent labour to the Social Partners Office and to European Institutions henceforth. ${ }^{93}$

\footnotetext{
${ }^{91}$ Degryse and Tilly, 2013, 15

${ }^{92}$ Interesting negotiations took place in order to bring in more hesitant organizations into the fold. It was agreed that one Deputy Secretary General would always be from a Nordic country and that at least one member of the Secretariat would come from a Christian trade Union (Degryse and Tilly, 2013, 68).

${ }^{93}$ Degryse and Tilly, 2013, 72
} 


\section{Section 3.4: From Crisis to Neoliberalism}

In 1971, US president Richard Nixon unilaterally terminated the US Dollar (USD) gold standard and ended the Bretton Woods Monetary System. Since the end of WWII, the fixed value of the USD was the backbone of the international monetary system in the capitalist world. When the USD was allowed to float, relative value of different currencies became unclear and inflations shot up as each country tried to navigate new monetary policy. ${ }^{94}$ Two years later, Europe was pushed further into crisis when the Organization of Petroleum Exporting States (OPEC) established curtailed oil, increasing the price of a barrel from \$3 to \$12 USD. At this point, industry in Japan and across Europe had fully recovered from the war, and competition across the Advanced Capitalist World was leading to a crisis of over- accumulation. In this context, the profits of capitalists were being squeezed by increased costs of production and wellorganized labour movements on one side and increased competition between capitalists on the other. ${ }^{95}$ By the mid-1970s, Europe was in a period of high inflation, economic stagnation and high unemployment that would last for more than a decade. ${ }^{96}$

As Keynesian based policies proved unable to reverse economic hardship, policy makers increasingly turned to neoliberal theory for answers. The European business community argued that labour market rigidities were to blame for the stagflation and the high unemployment that Europe was experiencing. In government, the business community was well represented by their traditional Conservative political party allies. On the other hand, Socialist and Social Democratic parties seemed unable to forward the interests of labour. Throughout the twentieth century, the role of most political parties in the European countries and across the rest of the Advanced

\footnotetext{
${ }^{94}$ Panitch, L. (2008). American empire and the political economy of global finance. Houndmills, Basingstoke, Hampshire [England: Palgrave Macmillan.: 29

${ }^{95}$ Panitch, 2008, 26

${ }^{96}$ Degryse and Tilly, 2013, 25
} 
Capitalist World changed in that political parties by and large became increasingly integrated into their respective state institutions. In a sense, they practically became an extension of the state apparatus in that they began to perform the state function of compromise facilitators/enforcers rather than the political representatives of their traditional electoral bases. ${ }^{97}$ As the power relation between capital and labour shifted in favour of the former, left wing parties were increasingly defined in relation to the priorities of the neoliberal policy set. In consequence, many trade unionists believed that left wing parties often became the begrudging facilitators of capital deregulation, austerity and privatization when they were in power. ${ }^{98}$

In European-level institutions, the Commission established the Standing Committee on Employment (SCE), a tripartite system where the European Commission, UNICE and the ETUC would meet and make joint recommendations to the Member States. Unlike the Social Partners' Office, which focused primarily on social policy, the Standing Committee on Employment was established to focus directly on factors related to employment. The ETUC soon found that the Standing Committee was a hostile environment. UNICE pushed for the elimination of barriers that they claimed had limited the success of corporate Europe. They also demanded wage benefits concessions from European workers. Even after the ETUC had made significant concessions on labour flexibility and wages, they still found that neither the EC nor UNICE would recognize their demands. The ETUC withdrew from the SCE in 1976. Many trade union leaders still feel that the ETUC has made too many concessions in order to preserve the legitimacy of the institutions that gave it privileged institutional power. ${ }^{99}$

\footnotetext{
${ }^{97}$ International Labour Organization Executive 1 (2013 September 27), Personal Interview; Europeanlevel Labour Organization Executive 4 (2014 November 21), Personal Interview;

${ }^{98}$ International Labour Organization Executive 1, (27 September 2013): Personal Interview

${ }^{99}$ Degryse and Tilly, 2013, 96
} 
The next few years continued to be difficult for labour. From 1979 to 1981, the United States Federal Reserve increased interests rates from 8 to 19 percent, which sucked investment and jobs out of Europe and into the United States. ${ }^{100}$ Neoliberalism was gaining steam and was being championed across the EEC by popular politicians such as Margaret Thatcher. New financial instruments had allowed capital to cross borders more easily and manufacturing and production was now taking place on an increasingly international scale as a result. Workers were being pushed into competition with their counterparts in other countries and were under great pressure to work for less. In contrast, as production was increasingly being controlled by financial capital and as international competition between capitalists concentrated corporate ownership; the interests of the capitalists were increasingly homogenized class. ${ }^{101}$

It was clear that the up-scaling of industrial relations would require labour to adapt, and it seemed, at least in the eyes of the ETUC, that structural options were no longer working. ${ }^{102}$ As illustrated in Graph 3.1, unemployment had also increased dramatically across Europe and it was clear that new strategies were needed. ${ }^{103}$

\footnotetext{
${ }^{100}$ Panitch, 2008, 31

${ }^{101}$ Horn, 2012, 579

${ }^{102}$ National Labour Representative 1 (2013 October 30): Personal Interview

${ }^{103}$ European-level Labour Organization Representative 2 (2013 November 12): Personal Interview
} 
Graph 3.1 - Unemployment in Selected Countries (Percentage) ${ }^{104}$

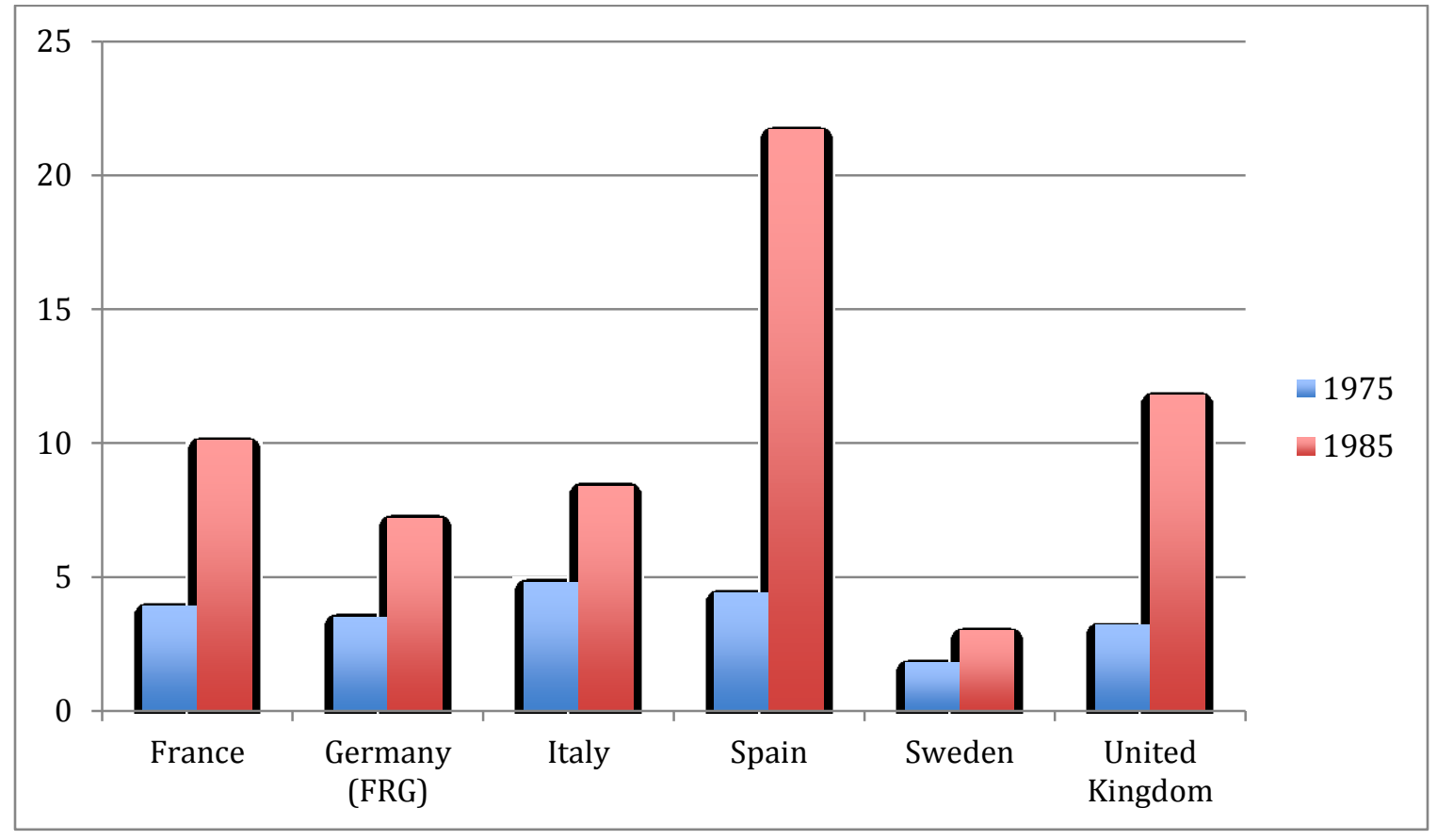

In 1985, European Commission president Jacques Delors presented an option to the ETUC that many thought would be in the interests of labour. In that year, he brought the ETUC and UNICE together for the Van Duchesse Summit to negotiate the Social Protocol, which was designed to operationalize the Social Dialogue. Unlike the Standing Committee on Employment, Delors planned to give the Social Partners the power to negotiate framework agreements related to social policy and production, which would be binding to the Member States after being operationalized by the Commission. UNICE was initially reluctant to engage in the Europeanlevel labour discussions. For them, it was clear that they had gained an advantage from increased competition between European workers, and Europe-level discussions could potentially allow labour to increase their solidarity and thus their institutional and structural power. At the time, it also seemed that the Social Dialogue could potentially open the door to trans-Europe industrial

${ }^{104}$ Derived from (Ross and Martin, 1992) 
relations, as well. However, Delors, a member of the French Socialist party and a trade unionist, famously told UNICE that "If you want the single market to be completed, then you must obtain the support of the trade unions". ${ }^{105}$ UNICE obviously regarded the single market as a priority, and eventually agreed to join the Social Dialogue.

For the labour movement, the pros and cons of such an arrangement were hotly contested. On the one hand, the labour movement clearly noted the race to the bottom in corporate taxes and wages and was aware that the labour movement needed some kind of a European-level presence. On the other hand, the past experience of labour with the SCE had made labour skeptical of the European institutions. Moreover, a convention known as the Luxembourg Compromise had allowed for nation-based unions to lobby the EEC via their respective representatives effectively in the past. The Luxembourg Compromise gave each minister in the Council of the European Communities a veto power over any decisions that were made by the Council. Though the Compromise is not mentioned in any treaty, it was enforced in order to protect each Member State from being forced to enact legislation that it believed was counter to its interest. ${ }^{106}$ It was also argued that in the act of engaging in the Social Dialogue they were making themselves complicit in the construction of a structure that would undoubtedly lead to the intensification of competition between workers and increased capital mobility. Moreover, many worried that by taking the Commission funding associated with the role of being a social partner, the ETUC would become financially dependent on the Commission, and would not be able to oppose the Commission in any meaningful way. ${ }^{107}$

\footnotetext{
${ }^{105}$ Greenwood, Justin. Interest representation in the European Union. Third Edition ed. Houndmills, Basingstoke, Hampshire: Palgrave Macmillan, 2011.: 94

${ }^{106}$ Abbott, Keith. "The ETUC and its Role in Advancing the Cause of European Worker Participation Rights." Economic and Industrial Democracy 19, no. 4 (1998): 605-631.: 612

${ }^{107}$ European-level Labour Organization Executive - 4 (2013, November 13): Personal Interview; National Labour Organization Executive 1 (2013, Novmber 13): Personal Interview
} 
When the Commission released the publication entitled Completing the Internal Marketwhich lay down a path to make the single market a reality by 1992 - it became clear that the single market was going to happen with or without the labour movements input. ${ }^{108}$ Thus the ETUC agreed to the Social Protocol and endorsed the Single European Act. However, due to opposition from several Member States, the Social Protocol was not included in a treaty until 1992. In becoming a Social Partner and endorsing the Single European Act, the ETUC became an active partner in the project of the European integration. The ETUC believed that they would be able to influence industrial relations more effectively through its participation in - rather than opposition to - the European integration.

In 1986, The Single European Act was put before the Member States for debate. If passed, it would put Europe on a path towards becoming a single market in 1992. It was clear that it would be difficult to ratify in many countries and Delors was actively seeking the support of the ETUC. The ETUC found itself in a position where they were able to negotiate and had Article 118a added to the Act. This article up-scaled any issue related to the health and safety of workers. It also established that Qualified Majority Voting (QMV), rather than the unanimity of the Luxembourg Compromise, be used in the Council of Ministers on health and safety issues. QMV required that a bill needed only seventy-five percent of the vote, which was weighted according to the relative population of each Member States. ${ }^{109}$ In moving health and safety to the European-level, the Member States were not able to increase their economic competitiveness by lowering safety standards. In addition, it also empowered the European Parliament which was

\footnotetext{
${ }^{108}$ Degryse and Tilly, 2013, 39

${ }^{109}$ European Union. "Single European Act," 17 February, 2007. European Union Treaties and Other International Agreements.

As of November, 2014 the QMV system well be replaced by a 'double majority system', where a qualified majority will be made up of 55 percent of the Member States (15 out of 28) representing sixtyfive percent of the population of the EU. It also states that a blocking minority must be made of at least four countries (European Union, Treaty of Lisbon, 13 December 2007).
} 
no longer obliged to accommodate the wishes of every single council minister. This in turn, empowered labour's Social Democratic and Socialist allies in the EP. The Treaty also obliged the Commission to consult the European Economic and Social Committee (one-third of which was made up of labour organizations) on issues related to social or economic policy. ${ }^{110}$

Yet, the Single European Act obviously posed a major threat to the labour movement. Transnational financial capital was clearly gaining ground when it came to structural power in Europe. Foreign investment in Europe was increasing dramatically, as was unemployment. Between 1980-1985, foreign investment averaged \$2.84 billion USD per annum; this increased 2.5 fold to $\$ 7.22$ billion per annum between 1986-1992. As the interests of capital became increasingly international, they became less dependent on single industries or locations and work action became less effective. Moreover, as unemployment increased, workers were more willing to work for less and it was difficult to maintain solidarity. ${ }^{111}$ In short, capital was continually gaining ground on labour from increased market integration and the up-scaling of the production process - the primary objectives of the Single European Act. The ETUC had clearly hoped that by engaging with the process, they would be able to provide input into the system that would be in favour of the labour movement. However, as production was transnationalized and neoliberalism was entrenched, capital gained power in relation to the working class. This power was then institutionalized and entrenched into the structures of the European Union. Thus, as the institutions of the EU took shape throughout the 1990s and 2000s, the ETUC was able to advance the interest of the working class interests in some instances, however, labour organizations clearly played second fiddle to their counterparts in the private sector. ${ }^{112}$

\footnotetext{
${ }^{110}$ Find citation

${ }^{111}$ Ross and Martin, 1992, 21

${ }^{112}$ National Labour Representative 1 (2013 October 30): Personal Interview
} 


\section{Section 3.5: The European Union and the turn of the Century}

The 1990s would prove to be a formative decade for the European Union, and one that would see significant strides toward up-scaling industrial/class relations in Europe. Across Europe, the establishment of several EU-level institutions forced national-level organizations to give more consideration to up-scaling their representation and strategies to account for the European-level. The pressure on the working class to up-scale their operations received varying responses across the continent. According to one British participant, though the rank and file in the UK was generally anti-Europeanization, the trade union executives were anxious to see more power moved to Brussels after years of conflict with the hostile Thatcher government. It is worth noting that the British trade union General and Municipal Workers was one of the first nonBelgian national trade unions in Europe to establish a European office in Brussels. ${ }^{113}$ In postSoviet states, the population was still suspicious of unions, which had been used by the Soviets as tools to control workers. Two participants from the Baltic States stated that many Eastern unions saw ETUC affiliation and EU participation as a way to rebrand and legitimize their organizations. ${ }^{114}$ In countries such as Germany, the Netherlands and Belgium, where trade unions were well resourced and had significant influence on domestic politics, they saw little value in EU-level organizing, but also saw little harm in dedicating some resources to EUrepresentation. ${ }^{115}$ In Southern Europe, a participant from that region hypothesized that where labour organizations had very little formal power, there was a lot of optimism regarding EUlevel organization. ${ }^{116}$ While predispositions ranged from skeptical to optimistic, the ETUC saw

\footnotetext{
${ }^{113}$ National Labour Organization Representative 5 (2013 November 20): Personal Interview

${ }^{114}$ National Labour Organization Representative 9 (2013 November 22): Personal Interview; National Labour Organization Representative 7 (2013 November 22): Personal Interview

${ }^{115}$ National Labour Organization Representative 1 (2013 October 30): Personal Interview

${ }^{116}$ National Labour Organization Executive 2 (2013 December 2): Personal Interview
} 
very little actual hostility from within the movement. It was clear that the European project was going ahead, and while it was still unclear if European-level industrial/class relations would come to fruition, the potential risk of being unrepresented within the maturing new institutional level was incentive enough for most to participate in good faith. ${ }^{117}$

Throughout the decade, ETUC stayed true to its commitment to support the establishment of a single European market and to a strategy based on increased institutional power. ${ }^{118}$ This is not to say that the labour movement as a whole had abandoned structural forms of power, on the contrary, the ETUC also played a significant role in coordinating the structural efforts of its members. Most notably, in April 1993, the ETUC led coordinated demonstrations in over 150 locations that involved over one million workers to protest the austerity policies that were being implemented across the EU to meet the financial requirements dictated by the newly signed Maastricht Treaty. ${ }^{119}$ That said, the organization's commitment to institutional approach, and the lack of follow up to the demonstrations in 1993 leads one to assume that those demonstrations were more about maintaining legitimacy in the eyes of the more militant labour groups than about applying structural power on capital or the state. ${ }^{120}$ In 1993, the Maastricht Treaty finalized the promise of the Single European Act to create an Economic and Monetary Union (EMU) and legislated the historical creation of the euro, which would be introduced ten years later. ${ }^{121}$ However, in order to comply with the financial requirements of the EMU, Member States were required to keep their debts below 60 percent of their GDP and hold their deficits to less than 3 percent of their GDP. Across Europe, both nationalist groups and left-leaning organizations

\footnotetext{
${ }^{117}$ MEP 1 (2013 September 24): Personal Interview; National Labour Organization Representative 5 (2013 November 20): Personal Interview

${ }^{118}$ National Labour Organization Executive 1 (2013 November 13): Personal Interview; MEP 2 (2013 November 12): Personal Interview

${ }^{119}$ Degryse and Tilly, 2013, 46

${ }^{120}$ European-level Labour Organization Executive 1 (2013, September 27): Personal Interview

${ }^{121}$ Degryse and Tilly, 2013, 47
} 
opposed the financial requirements of the EMU. For the left, the austerity that would be needed in order to abide by these restrictions was far too harsh, and nationalist groups saw it as an unacceptable handover of national sovereignty to Brussels. ${ }^{122}$

In this climate, the support of the ETUC was seen as important to the political viability of the Treaty. The ETUC used this situation to its advantage and negotiated the extension of Qualified Majority Voting to legislation related to working conditions, gender equality in the work place, inclusion of persons excluded from the labour market and information and consultation of workers. ${ }^{123}$ It also successfully worked with UNICE to have the Social Protocol annexed to the Maastricht Treaty. ${ }^{124}$ The ETUC support helped push through some very narrow victories in favour of the Maastricht Treaty. In France, ratification of the treaty was approved only by the narrowest of margins; 51 percent in favour to 49 percent against. In Denmark, ratification initially failed and had to be approved by a second referendum after several of Denmark's conditions were met. ${ }^{125}$

The Social Protocol was particularly important aspect of the Maastricht Treaty, as it gave the Social Partners an avenue to influence the European labour law and established the powers of the Social Partners in the EU structure. Throughout the latter half of the 1990s, the Social Dialogue produced several framework agreements that were operationalized by the Commission. In 1995, it produced the Framework Agreement on Parental Leave, in 1997 the Framework Agreement on Part-Time work and in 1999 the Framework Agreement on Fixed-Term Contracts was entrenched by a directive from the Commission. All of these agreements represent tangible victories that the labour movement achieved through participation in the European level

\footnotetext{
${ }^{122}$ Degryse and Tilly, 2013, 47

${ }^{123}$ Greenwood, 2007, 96

${ }^{124}$ The Conservative government of the UK prevented the Social Protocol from being included in the treaty outright.

${ }^{125}$ Degryse and Tilly, 2013, 47
} 
institutions. ${ }^{126}$ These framework agreements went a long way to raise the profile of the ETUC. However, for many in the European labour movement and the view of many participants, the ETUC had betrayed workers by endorsing a treaty that caused harsh austerity across the EU. ${ }^{127}$

The ETUC continued to represent labour in treaty negotiations throughout the 1990s. In particular, the ETUC was very aggressive in negotiating the Treaty of Amsterdam after the Conservatives were defeated by the Labour Party in the United Kingdom. In doing so, the Treaty of Amsterdam established a 'high-level of employment' as an objective for the Union, and established democracy, and freedom from discrimination due to disability, age, sexual orientation, race, ethnic origin, sex or religion as fundamental rights of the European citizenry. ${ }^{128}$ Furthermore, after the then UK Prime Minister Tony Blair withdrew British opposition, the Social Protocol was fully incorporated into the Treaty of Amsterdam. ${ }^{129}$ However the Treaty also founded the European Employment Strategy (EES), an institution based on the model of the Open Method of Coordination (OMC). This was significant in that the EES provided the first institutional and formal avenue for the Commission and the European Council to evaluate and influence the socioeconomic and industrial relations policy of the Member States. ${ }^{130}$

In the Treaty of Amsterdam, the EU institutionalized the Open Method of Coordination $(\mathrm{OMC})$ for the first time with the creation of the European Employment Strategy (EES). According to the European Union's website, "the open method of coordination takes place in areas which fall within the competence of the Member States, such as employment, social

\footnotetext{
${ }^{126}$ Degryse and Tilly, 2013, 102

${ }^{127}$ International Labour Organization Executive 1 (2013 September 27): Personal Interview; EP Employee 2 (2013 November 12): Personal Interview; European-level Labour Organization Executive 4 (2013 November 21): Personal Interview

${ }^{128}$ Greenwood, 1997, 101

${ }^{129}$ Degryse and Tilly, 2013, 102

${ }^{130}$ MEP 2 (2013 November 12): Personal Interview
} 
protection, social inclusion, education, youth and training." ${ }^{, 131}$ In the case of the EES, the Commission was authorized to establish employment targets for each Member State after incorporating their input. The Member States were then obliged to present national action plans, which outlined how they planned to reach those targets in concrete terms. In the third step, the Commission published a report that documents the progress or regression of each Member State. It is notable that neither the European Court of Justice nor the European Parliament play any role in the EES. ${ }^{132}$ While many hailed the EES as an innovative mechanism that allowed for policy learning among Member States, the EES also proved to provide the Commission with an avenue to influence employment policy for the first time. A decade later, when the Eurozone crisis began, the EES became the foundation of Europe2020 and legitimized the Commission taking a more coercive role in relation to its Member States. ${ }^{133}$

By the turn of the new millennium, neoliberalism and the up-scaling of production and industrial relations has presented the working class with serious challenges since the Single European Act was instituted. The up-scaling of socioeconomic policy had gone further than most had predicted. As of 2001, 80 percent of the economic measures passed by national legislators in the EU Member States had come down from EU institutions. ${ }^{134}$ Structurally, the working class had lost ground to capital. From 1993 to 2003 union density in Europe had declined by one-sixth and unemployment had continued to climb across the EU. ${ }^{135}$ While a few ETUFs and other organizations were able to push back against a race to the bottom, capital had been successful in using new financial instruments to transnationalize production and take advantage of

\footnotetext{
${ }^{131}$ The Open Method of Coordination. (n.d.). Retrieved January 15, 2015, from http://europa.eu/legislation_summaries/glossary/open_method_coordination_en.htm

132 The Open Method of Coordination. (n.d.). Retrieved January 15, 2015, from http://europa.eu/legislation_summaries/glossary/open_method_coordination_en.htm

${ }^{133}$ European-level Labour Organization Executive 4 (2013 November 21): Personal Interview

${ }^{134}$ Greenwood, 2007, 49

${ }^{135}$ Greenwood, 2007, 94; Martin and Ross, 1999, 17-18
} 
international competition and high unemployment rates to apply downward pressure on wages and benefits. These problems were compounded when ten new countries were incorporated into the EU in 2004. ${ }^{136}$ Many trade unionists pointed out that the inclusion of the new Member States created greater disparity and economic competition between EU-workers. ${ }^{137}$

Institutionally, it had seemed as though the labour movement made progress during the 1990s, especially at the European level. However, at the time it is not clear how effective this power was in the absence of structural influence. One the one hand, the labour movement had gained privileged access and institutional representation that far exceeds anything else in the advanced capitalist world. However, as pointed out by Horn, the labour movement lacks access to several departments of the Commission, the so-called Directorate-Generals (DGs), which also influence the reality of the working class. Most notably, while labour organizations have great access to the DG Employment and Social Affairs, neither the ETUC nor other labour organizations have significant access to the DG Environment, DG Education and Culture or Taxation and Trade - and perhaps most importantly - to the DG Internal Market and Services. ${ }^{138}$ As explained in Chapter 2, the structure of a state apparatus is reflective of the relative social, political and economic power of the interests that are represented by the various branches of the state. That is to say, the relative power of the various Directorate Generals and the influence of capital and labour therein, is a reflection of the power that the two classes have elsewhere in society. Thus, due to the fact that capital has more structural power than labour, it has been able to garner more influence throughout the European Commission and throughout the structures of the European Union.

\footnotetext{
${ }^{136}$ National Labour Organization Representative 7 (2012 November 22): Personal Interview

${ }^{137}$ European-level Labour Organization Executive 2 (2013 September 26): Personal Interview; International Labour Organization Executive 1 (2013 September 27): Personal Interview

${ }^{138}$ Horn, 2012, 583
} 
The same concept is relevant when it comes to other aspects of the institutional power of the working class. The ETUC had considerable success in advancing a social discourse in European treaties throughout the 1990s. However, while these accomplishments were important, very few of them actually countered the interests of capital. For example, while gender equity and health and safety in the work place are important, the application of these new regulations did not hinder the ability of capitalist to continue to accumulate wealth. When it came to issues that directly influenced the distribution of capital between the classes such as wages and job security, capital has clearly been the victor. Again, while the ETUC did have considerable success in negotiating the three aforementioned framework agreements in the Social Dialogue, however the majority of the participants felt that when weighed against the ETUC's overall support for the single market and flexicurity, many claim that the ETUC has had to surrender too much and gained too little. ${ }^{139}$

In the judicial branch of European government, the labour movement did have some early success with the European Court of Justice, however the ECJ delivered crushing defeats to the labour movement in the Laval (C-341/05) case and Viking (C-438/05) case rulings in 2005 and the Rüffert case ruling (C-346/06) in 2006. The decisions of the ECJ in the Laval and Viking established a precedent whereby the right to strike could not interfere with the principles of the single market and the ruling in the Rüffert case established that the right to provide a service has primacy over wage agreements established through collective bargaining. ${ }^{140}$

Politically, Social Democratic and Socialist parties at both the national and EU level had changed "from mass organizations of workers to bureaucratic organizations strongly integrated

\footnotetext{
${ }^{139}$ EU Employee 1 (2013, November 12): Personal Interview; MEP 2 (2013, November 12): Personal Interview: National Labour Organization Executive 2 (2013, December 2): Personal Interview: International Labour Organization Executive 1 (2013, September 27): Personal Interview

${ }^{140}$ Greenwood, 2011, 111
} 
into the state apparatus". ${ }^{141}$ That is to say that they no longer specifically represented the interests of the working class. In becoming part of the state apparatus, they had become part of the institutional structure that developed and that now enforces class compromise, according to the relative power of the two classes.

It is however important to note that structural and institutional power are interconnected and mutually reinforcing. The ETUC has played an important role in connecting the labour movement across the EU and in connecting organized labour to other civil society organizations grounded in the working class. ${ }^{142}$ With regards to building connections to the labour movement, the ETUC and its partners have had considerable success in implementing a benchmark system, which helped labour organizations coordinate their bargaining with their counterparts in other countries and avoid competition between unions and a race to the bottom. ${ }^{143}$ Across Europe, most unions and labour organizations have recognized the importance of the transnational level. In 2012, 92 percent of nation-level trade unions claimed that they shared information with each other on a regular basis, that 71 percent cooperate in joint training exercises for their staff and members, 52 percent had coordinated negotiations related to the transnational restructuring of firms and/or plant closures and 38 percent had sent representatives to other countries to sit as an observer on collective bargaining procedures. ${ }^{144}$

It is unclear if a different strategy would have had greater success at the European-level. What is clear is that in the quarter century previous to the crisis, the up-scaling of the production process and of class relations - in the form of industrial relations, in politics and in law - the

\footnotetext{
${ }^{141}$ International Labour Organization Executive 1, (27 September 2013): Personal Interview

${ }^{142}$ National Level Labour Organization Executive 1 (2013, November 13): Personal Interview

${ }^{143}$ Greenwood, J. (2011). Interest Representation in the European Union (Third ed.). Houndmills, Basingstoke, Hampshire: Palgrave Macmillan.:114

${ }^{144}$ Larsson, B. (2012). Obstacles to transnational Trade Union Cooperation in Europe - Results from a European Survey. Industrial Relations Journal. 43(2). 152-170: 159
} 
working class has clearly lost structural power in comparison to capital. In the eyes of policy makers, organized labour was either unwilling/unable to encumber the production process and thus meeting their demands was not a prerequisite for the continued accumulation of capital. In contrast, neoliberal policy champions support of financial capital as a foundational strategy for facilitating the societal accumulation of capital. Neoliberal policies have since become the foundation of the European project, the top priority of the ECB, the Commission and the ECJ is explicitly to facilitate the free movement of capital, to maximize efficiency, minimize production costs and to provide a stable and secure market for financial investment. ${ }^{145}$ Thus, while labour has made significant institutional gains, the European Union has intentionally tied the success of the European production to that of the financial sector. One international trade union executive felt that the EU has explicitly designed its laws and institutions to help secure that success. ${ }^{146}$ The disadvantage of labour to capital is institutionally entrenched and systemically supported. When the Eurozone Crisis began, financial capital was structurally more powerful than organized labour. Policy makers were fully aware that if financers lost faith in the European economy that the productive capacity of Europe could be greatly diminished. In contrast, organized labour did not seem to have the capacity to cause a long-term disruption in terms of an ongoing strike or mass protest. In consequence, as the crisis continued, policy makers continually enacted regulations to protect the interests of the financial sector, and ordinary working people were made to carry the burden of the crisis. ${ }^{147}$

\footnotetext{
${ }^{145}$ MEP 2 (2013 November 12): Personal Interview; EU Employee 1 (2013 November 12): Personal Interview; Horn, 2012, 582

${ }^{146}$ International Labour Organization Executive 1 (2013 September 27): Personal Interview

${ }^{147}$ International Labour Organization Executive 1 (2013 September 27): Personal Interview; Europeanlevel Labour Organization Executive 4 (2013 November 21): Personal Interview
} 


\section{Chapter 4: The Crisis}

\section{1: Chapter Introduction}

Chapter 3 showed that over the course of the last quarter century the structural power of the European working class continually waned in comparison to capital. Over that time period, capital won several important victories related to the construction of the European Union. In doing so, capital managed to entrench neoliberal principles into the EU structure and cement a long-term institutional advantage for the capitalist class. As such, capital has seemly gained a significant and deepening advantage in industrial relations through EU and Member States' socioeconomic policy. Accordingly, legislators, judiciaries and other state institutions have continually acted in favour of the capitalist class; most notably by facilitating the long term decline of the welfare state and by simultaneously limiting the collective power of workers while removing restrictions on capital. This has been a long-term trend that continued into, and was exacerbated by the Eurozone Crisis. One trade unionist even went as far as to say that "the crisis is a coup de grâce to the social system."148

When the Eurozone crisis first set in, policy makers strived to accommodate the needs of capital, frequently going so far as to take private toxic debt incurred onto public books in order to save the financial sector from insolvency. Ireland and Spain were actually pushed to the brink of bankruptcy by their attempts to support the needs of financial capital. In contrast, the standard of living for workers has declined across the EU, unemployment has skyrocketed, social spending and benefits have been cut and union density has been diminished in 17 of the 18 Eurozone

\footnotetext{
${ }^{148}$ International Labour Organization Representative 1(2013 October 26): Personal Interview
} 
countries. ${ }^{149}$ The labour movement has struggled to defend the welfare of the European working class while capital has thrived. ${ }^{150}$

When the EU was being formed, issues related to industrial relations and social policy fell outside of the competencies of the Union. However, as of 2001, 80 percent of socioeconomic policy passed by national legislators had been initiated in response to EU directives. ${ }^{151}$ During the crisis, mechanisms like the European Employment Strategy and Europe2020 gave the European Commission an avenue to speak directly, and with great influence, to issues related to employment and social policy. In 2012, the Commission used these mechanisms to make country-specific recommendations on wage policy for 17 out of 18 of the euro zone countries. ${ }^{152}$ In the report for 2015, the Commission found that 16 of the 18 countries continued to have macroeconomic imbalances. Accordingly it recommended the continued 'modernization' of labour and welfare policy to improve labour market flexibility and to take steps to continue to support investment in the private sector. ${ }^{153}$

This chapter first focuses on the case study of Greece, which became the first Member States to get hit by the crisis in 2009. This case study was used to show how in Greece, like in the Member States more broadly, the socioeconomic policy fall within a spectrum that is defined by the institutions of the EU. The next section focuses on the cases of the other crisis-hit countries in lesser detail. The purpose of these case studies is to identify the commonalities

${ }^{149}$ Benchmarking working Europe 2013. Brussels: ETUI-REHS, 2014.; OECD. "Trade Union Density." Trade Union Density. http://stats.oecd.org/Index.aspx?DataSetCode=UN_DEN\# (accessed April 14, 2014).

${ }^{150}$ Horn, 2012, 577; International Labour Organization Executive 1 (2013 September 27): Personal Interview

${ }^{151}$ Greenwood, 2007, 49

${ }^{152}$ ETUI, 2013, 43

153 "Communication From the European Commission to the European Parliament, The Council, The European Central Bank and the Eurogroup." European Commission. European Union, 26 Feb. 2015. Web. 25 Apr. 2015. <http://ec.europa.eu/europe2020/pdf/csr2015/cr2015_comm_en.pdf $>$.: 6,8 
between them and to show a) that while causes of the crises of each country were unique and multifaceted, financial capital had a direct role in causing the crisis in each country, b) in each case, the needs of capitalists were protected while working class standards of living were sacrificed and c) the responses for the crisis were manufactured at the European level.

Section 4.3 examines the ways in which labour organizations responded to austerity across the EU. This section also provides an in depth analysis on the factors that currently limit the structural and institutional power of labour. It concludes that the structural power of labour organizations is limited by the a) the logistical and cultural difficulties associated with transnational solidarity, b) the disconnect that exists between labour organizations, their membership and the broader working class and c) the notable absence of a developed alternative to neoliberalism that is championed with consistency by union discourse. With regards to institutional power, it is clear that the traditional alliance with Social Democratic political parties and dependence on the EESC and the Social Dialogue has not been sufficient in forwarding the interests of labour. It is difficult to say what role these factors do play influencing EU policy, however what is clear is that capital has significantly more institutional power than labour. ${ }^{154}$

The final section reviews the findings of this chapter and examines the potential that alliances between labour organizations and new social movements presents for the working class with regard to the building of solidarity and of a common identity of the European working class. There within, I draw on common experiences identified in my research that could serve as the foundation of such an identity.

\footnotetext{
${ }^{154}$ International Labour Organization Executive 1 (2013 September 27): Personal Interview
} 


\section{Section 4.2: The Crisis begins - the Case of Greece}

The beginning of the crisis is well documented. In the fall of 2009 , it was discovered that the outgoing New Democracy Party of Greece had hired Goldman Sachs to deceive the European Union and financial markets around the world by upholding the Greek government's manufactured claim regarding the level of Greek deficit. Up till that point, the Greek government had reported a 2008 deficit of just two percent. When the Socialists were elected, they informed the EU that the true deficit was 12.7 percent, and later corrected that figure to 15.4 percent in April 2010. ${ }^{155}$ During that year and a half, Greece also reported that its gross public debt had climbed from 105.4 to 127.1 percent of GDP between 2007 and $2009 .{ }^{156}$ The deception caused a great deal of uncertainty and rampant speculation in financial markets. As speculation continued, investors began to demand higher interests rates on Greek government bonds. By spring 2010, the high interests effectively barred the country from borrowing money from private markets.

By April 2010, Greece requested a $€ 45$ billion euro loan from the IMF and the European Union in order to avoid bankruptcy. A month later the Greek government and the Troika (the European Commission, the European Central Bank and the IMF) agreed to a $€ 110$ billion loan that was funded in partnership by the IMF and the Eurogroup. The loan came with the condition that the Greek State implement an Economic Adjustment Programme (EAP); a series of mandatory socioeconomic reforms that would take place under the supervision of the Troika. The loan was scheduled to be delivered in a series of thirteen tranches, providing that the Troika

\footnotetext{
${ }^{155}$ Busch, Klaus. Is the Euro failing? structural problems and policy failures bringing Europe to the brink. Berlin: Friedrich-Ebert-Stiftung, Internat. Policy Analysis, 2012.:18

${ }^{156}$ Karamessini, Maria. "Sovereign Debt Crisis: An Opportunity to Complete the Neoliberal Project and Dismantle the Greek Employment Model." A Triumph of Failed Ideas: European Models of Capitalism in the Crisis. Ed. Steffen Lehndorff. Brussels: ETUI Printshop, 2012. 155-182. Print. $: 165$
} 
was satisfied with Greece's efforts to meet the stipulations of the EAP. ${ }^{157}$ The aim of the EAP clearly bore a neoliberal design, with the objectives to a) address the rampant tax evasion problem in Greece, b) stabilize the Greek financial sector, c) improve the market viability of Greek public expenditure, primarily through significant spending cuts and d) improve the international competitiveness of Greece. ${ }^{158}$

As the crisis in Greece carried on, the risk of contagion increased. In this context, the Eurogroup established the European Financial Stability Facility (ESFS) and European Finical Stability Mechanism (EFSM) to administer bailout packages to any other country that might be hit by the developing crisis. ${ }^{159}$ It was also hoped that the ESFS would quell anxiety in financial markets. The ESFS was formed as a company registered in Luxembourg that could buy and sell bonds on capital markets and guarantee the debt obligations of EU Member States; a function that the ECB was unable/unwilling to perform at that time. The ESFS was originally provided with $€ 440$ billion which included $€ 60$ billion through the ESFM, which was guaranteed by the budget of the EU and controlled by the European Commission. The remaining $€ 380$ billion was guaranteed by every Member States in an amount proportionate to their holdings in the ECB. The ESFS could also buy crisis-hit countries' government bonds at interest rates that were favourable to the borrowing country. In effect, it was a way to lend capital to a crisis country at rates that were more affordable than what could otherwise be found in private markets. However, in order to access the ESFS, a crisis country first had to reach an agreement with the European Union and the IMF. ${ }^{160}$

\footnotetext{
${ }^{157}$ Busch, 2012, 10, 18

${ }^{158}$ Karamessini, 2012, 161 et seq.

${ }^{159}$ Busch, 2012, 10

${ }^{160}$ Busch, 2012, 12
} 
A year after Greece signed the agreement with the Troika, the Greek government narrowly passed the Medium-Term Fiscal Strategy 2012-2015 (MTFS) into law. In doing so, Greece engrained the requirements of the EAP into national law. This was the first of many instances where either the Troika or the Commission directly dictated socioeconomic policy to a Member States over the course of the crisis. The overarching goal of the EAP and the MTFS was to reduce the deficit by 11 percent of GDP by 2015 , or by 21.4 percent when accounting for the expected decline of the Greek economy. The plan called for two-thirds of the target to be reached by spending cuts and the other third from increasing government revenue. ${ }^{161}$

In the Greek public sector, austerity came in the form of 15 percent wage cuts for civil servants and 25 percent pay cuts for workers in publically owned utilities. The MTFS also called for massive layoffs; in 2011 one in every ten public employees were dismissed and another 10 percent were scheduled to be let go by 2015. The national workweek was increased from 37.5 to 40 hours, and the government decreased payouts in the public pension program by 10 percent. In addition, a new regulation was put in place that required workers to work forty years before being eligible for pensions with a penalty of six percent per year for early retirement. ${ }^{162}$

Public services were also decimated; the federal government reduced the number of municipal governments by two-thirds and dismissed 50 percent of their employees. New service fees were added in the healthcare industry while schools, clinics, hospitals and universities all saw their budgets dashed. ${ }^{163}$ The Troika also called on Greece to raise $€ 50$ billion by selling off or reducing its ownership share in publically held assets; including in its state owned energy

\footnotetext{
${ }^{161}$ Karamessini, 2012, 168

${ }^{162}$ Karamessini, 2012, 169

${ }^{163}$ Karamessini, 2012, 171
} 
companies, water utility, its shares in seaports, airports and railways, the national postal service and its national military arms manufactory. ${ }^{164}$

There were also several direct attacks on trade unions and industrial relations law. Minimum wage law was undercut by allowing individuals between 15 and 18 years of age to work for 70 percent of minimum wage and anyone under 25 to work for 84 percent if it was their first professional job. The state also legislated that non-unionized workers were no longer covered under collective agreements that had previously covered entire sectors. It also suspended collective bargaining for all civil servants and public utility workers and soon thereafter legislated the aforementioned wage cuts. Labour law was also adjusted in order to increase the flexibility of the work force and to lower the unit costs of labour. ${ }^{165}$ This resulted in an increase in the instances of precarious forms of labour and allowed for capital to accumulate a larger portion of the surplus value generated in the production process.

The hardship caused by the austerity policies caused a great deal of unrest in Greece. In particular, a grassroots movement called Direct Democracy Now! took aim at both the Troika and the national Greek government by organizing large scale and ongoing demonstrations across Greece. Political parties that offered alternatives to transnational capitalism also saw their popularity skyrocket. However trade unions were unable to mount much opposition to the austerity in Greece. One interviewee correctly noted that there have been more than 30 general strikes in Greece (as of 2013), none of which have lasted longer than a day. He went on to say that:

"The trade unions do small actions like this to get all of the aggression out, to control their members. They don't want to go further because their political

\footnotetext{
${ }^{164}$ Zacune, Joseph. "Privatizing Europe, Using the Crisis to Entrench Neoliberalism." TNI.org.

Transnational Institute, 1 Mar. 2013. Web. 24 Mar. 2015.

$<$ http://www.tni.org/files/download/privatising_europe.pdf $>$.: 9

${ }^{165}$ Karamessini, 2012, 172-173
} 
ideology is linked to the social democratic parties, and this creates complacency."

The insight of this participant is revealing. Throughout the 1980s and 1990s, Greek labour organizations had used a combination of work action and lobbying techniques to advance the interests of the working class. However, after the crisis hit, it was clear that supporting interests of capital were of greater importance for the ability of Greece and Europe to continue to accumulate capital than those of labour. ${ }^{167}$ The priority of both the neoconservative New Democratic Party and the Greek Socialist Party was to work with the Troika to support financial capital and create conditions conducive to the continued accumulation of capital in Greece. ${ }^{168}$ While mainstream political parties forged ahead with austerity, organized labour seemed incapable of championing an alternative discourse for the working class. One Greek interviewee from a trade union background claimed that in the context of the crisis, trade unions feared taking action that might damage the economy further. Thus the aim of their demonstrations and strikes were not to disrupt production, but to provide a controlled outlet for Greek workers to express their frustrations and to threaten disruption rather than to engage in it. ${ }^{169}$ However, as is discussed later in the chapter, most Greeks believed that trade unions were actually complacent about the austerity policy.

On the European front, transnational solidarity with Greek workers was limited to say the least. While it was common for labour organizations to denounce Greek austerity, there was less sympathy throughout the working class. As is common in media across the world, 'Greece' was often portrayed as a single entity, one that had deceived the rest of Europe and that had been

\footnotetext{
${ }^{166}$ International Labour Organization Executive 1 (2013, September 27): Personal Interview

${ }^{167}$ EC Employee 4 (2013, December 2): Personal Interview

${ }^{168}$ International Labour Organization Executive 1 (2013, September 27): Personal Interview

${ }^{169}$ EC Employee 4 (2 December 2013): Personal Interview
} 
living beyond its means. Though the suffering of Greeks had been well documented across the EU, workers in other countries regarded the situation in Greece as something that Greeks had brought upon themselves. Some interviewees felt that little effort was made to humanize the situation and differentiate between the roles that the Greek workers, capitalists and the state had played in the crisis. ${ }^{170}$ In this context, Greek workers were often characterized as lazy and sometimes are even named as the scapegoats of the crisis. ${ }^{171}$ Contrary to that perception, the fact of the matter is that in 2008 , the average Greek worker worked more hours per years (2 152) than their German (1 430) or Norwegian (1422) counterparts. ${ }^{172}$ Regardless, the popular discourse seemed to suggest that Greece had broken the rules and now Greeks had to play the price. ${ }^{173}$

At the time of writing, the crisis continues in Greece. The most recent data indicates that unemployment averaged at 26 percent in 2014 and 58.6 percent for workers aged 18 to 25 . Furthermore, the unit cost of labour decreased by 21.6 percent between 2009 and 2014. However, the Commission regards the latter figure as a victory and was encouraged by Greek action "such as wider use of decentralized wage bargaining and a lower minimum wage... to lower the compensation per employee." 174 The Commission encouraged Greece to continue to apply pressure to wages in order to regain the competitive advantage it enjoyed in the early 1990 s. ${ }^{175}$

\footnotetext{
${ }^{170}$ European-level Labour Organization Executive 1 (2013 September 26): Personal Interview; International Labour Organization Executive 1 (2013 September 27): Personal Interview National Labour Organization Representative 7 (2013 November 22): Personal Interview

${ }^{171}$ National Labour Organization Representative 5 (2013 November 8): Personal Interview

${ }^{172}$ Wahl, Asbjorn. "European Labor: Political and Ideological Crisis in an Increasingly More Authoritarian European Union." Monthly Review 65, no. 8 (2014). http://monthlyreview.org/2014/01/01/european-labor (accessed March 3, 2014): 3

${ }^{173}$ EU Employee 1 (2013 November 12): Personal Interview

${ }^{174}$ European Commission (c) Commission Staff Working Document: Assessment of the 2014 National Reform Programme for Greece. European Commission. 2014. 9

${ }^{175}$ Ibid, 11
} 
Throughout the crisis, the EU played a major role in socioeconomic policy of its Member States, and especially in crisis countries. In each instance, domestic and transnational financial institutions played a major role in instigating the crisis and workers were made to suffer for it. Equally similar among the EU Member States was that the crisis response was nearly completely dictated, or at least guided with a heavy hand, from the European level. Lastly, in every case, labour organizations were unable to sufficiently limit the advances made by capital. 


\section{Section 4.3: Other Cases of Crisis}

\section{Portugal:}

Portugal did not come into the crisis from a position of power and was in a weak economic standing even before the crisis began. Its manufacturing sector had never achieved the high level of technological advancement enjoyed in Northern Europe and had traditionally relied on low-tech production for employment. After the EU expanded to include Slovenia, Slovakia, Poland, Malta, Lithuania, Latvia, Hungary, Estonia, Cyprus and the Czech Republic in 2004, the country also had trouble competing in low-tech manufacturing. Since that point, Portuguese workers had continually lost jobs to social dumping. ${ }^{176}$ However, it is worth noting that national Portuguese trade unions had led an effective campaign in partnership with several ETUFs to coordinate collective bargaining strategies across the EU in order to mitigate social dumping. ${ }^{177}$

When the world financial crisis, and later the Eurozone crisis set in, the already weak Portuguese economy continued to deteriorate. Eventually, private rating agencies downgraded Portugal's credit rating to the point where the country was effectively barred from borrowing capital on private markets. In April 2011, the country signed a Memorandum of Understanding with the Troika in order to gain access to a $€ 78$ billion loan. ${ }^{178}$ While the Memorandum was not officially an economic adjustment plan, it had similar implications for the country. The table below depicts the policy options that Portugal implemented to meet the demands of the Troika.

\footnotetext{
${ }^{176}$ Busch, 2012, 26; European-level Labour Organization Executive 4 (2013 November 21): Personal Interview

${ }^{177}$ European-level Labour Organization Executive 2 (2013 September 26): Personal Interview; Europeanlevel Labour Organization Executive 4 (2013 November 21): Personal Interview

${ }^{178}$ Busch, 2012, 28
} 
Table 4.1 Policies Implemented under the Portuguese MoU.

\begin{tabular}{|c|c|}
\hline Policy Area & Policy Action \\
\hline Public finances ${ }^{179}$ & $\begin{array}{l}\text { - Increase consumption tax, VAT and real estate tax } \\
\text { - Reduction in pay and overall employment in public sector } \\
\text { - } \quad \text { Freeze pension adjustments } \\
\text { - } \text { Cut welfare benefits } \\
\text { - Reduce unemployment insurance payouts } \\
\text { - Reduce healthcare and education funding } \\
\text { - Privatize publically owned assets in transportation, utilities and } \\
\text { telecommunication. }\end{array}$ \\
\hline Industrial Relations ${ }^{180}$ & $\begin{array}{l}\text { - Reduce severance payment policy from one month's pay for } \\
\text { every year of employment to } 12 \text { days pay. } \\
\text { - The elimination of four public holidays and the reduction of } \\
\text { three vacation days for full time employees. } \\
\text { - Increase in the number of hours that can be worked congruently } \\
\text { during a shift from five to six hours. } \\
\text { - } 50 \text { percent reduction in mandatory overtime pay } \\
\text { - The enactment of policies that encouraged the hiring of hire } \\
\text { non-unionized employees }\end{array}$ \\
\hline $\begin{array}{l}\text { Privatization (list of } \\
\text { public assets that were } \\
\text { privitized) }\end{array}$ & $\begin{array}{l}\text { Energy and Oil: } \\
\text { - GALP Energia SGPS (energy production) } \\
\text { - Redes Energeticas Nacionais, SGPS (energy infrastructure) } \\
\text { Water and Sanitation: } \\
\text { - Águas de Portugal, SA (water sanitation) } \\
\text { - Empresa Geral do Fomento, SA (waste sanitation) } \\
\text { Communication: } \\
\text { - Correios de Portugal (public postal service) } \\
\text { Insurance Sector: } \\
\text { - All three divisions of Campanhia de Seguros, SA, (financial, } \\
\quad \text { health, and life insurance company) } \\
\text { Air Transportation: } \\
\text { - TAP, SGPS (airline compnay) }\end{array}$ \\
\hline
\end{tabular}

\footnotetext{
${ }^{179}$ Busch, 2012, 28

${ }^{180}$ Guimardes, Pedro. "Portugal". Labour Market Reforms Tracker. London: Freshfields Brukhaus Deringer LLP. 2014. 31-35
} 
Privatization was also seen as a pillar of the MoU between Portugal and the Troika. It required Portugal to generate $€ 5$ billion (or three percent of GDP) by selling state owned assets by $2013 .^{181}$ One of the research participants pointed to privatization as one of the primary ways in which capitalists benefited from the crisis in Portugal. In the excerpt below, the participant expresses frustration with how capitalists played a major role in inducing, and then benefiting from the crisis.

I don't believe that Portugal has a problem, I think someone woke up one day and said 'okay first Greece, then Ireland, now Portugal. Portugal, we are downgrading your credit rating. Don't worry, you can still go to the markets, but at a higher rate.'... Next, they raise the interest rates so they cannot be paid. Then they say, 'okay, you are not doing good enough, you need an intervention, and yes we'll lower interest rates.' But this came at a price; they made us privatize everything in the country that was profitable. In the transport sector that was the case. We had to privatize the bus services, the boat services, the airline, everything had to go. ${ }^{182}$

While the quote may be slightly hyperbolic, it is true that Portugal sold off many of its most profitable state corporations during the crisis. This included divesting in three state-owned energy companies, the national airline (TAP Portugal), the public postal service (Correios de Portugal, CT), the public freight and railway companies, its stakes in the water and sanitation utilities, the state owned insurance company and the public financial service provider. ${ }^{183}$ Some participants felt that this policy decision was clearly driven by ideology and pressure from investors, as many of these companies were profitable and important sources of state revenue. ${ }^{184}$ For example, the state sold its 70 percent stake in CTT in spite of the fact that the company had

${ }^{181}$ Brauninger, Dieter. "Privatisation in the Euro Area: Differing Attitudes towards Public Assets." Deutsche Bank Research. Deutsche Bank Management, 20 Aug. 2013. Web. 5 Apr. 2015. $<\mathrm{https}$ ://www.dbresearch.com/PROD/DBR INTERNET ENPROD/PROD0000000000318583/Privatisation in the euro area: Differing attitud.pdf $>:: 10$

${ }^{182}$ European-level Labour Organization Executive 4 (2013 November 21): Personal Interview

${ }^{183}$ Brauninger, 2013, 10

${ }^{184}$ European-level Labour Organization Executive 4 (2013 November 21): Personal Interview 
constantly turned a profit before the crisis began. This was clearly a short-term solution that will have long-term consequences for state revenue. The sale generated $€ 579$ million, and in 2014 CTT returned a profit of $€ 77.2$ million. ${ }^{185}$ That means that the state would have garnered $€ 54$ million (nearly 10 percent of the revenue from the sale) had the state still held their 70 percent stake in the company. Likewise, TAP was a reliably profitable airliner that was fully owned by the state. Portugal also sold 40 percent of its state-owned energy company for $€ 592$ million and in 2014 alone, it generated a net income of over $€ 505.2$ million. $^{186}$

It is important to note that revenue generation was a secondary function of these organizations. Primarily, they were created and existed to provide services to the people of Portugal. However, when they were privatized, the priority became revenue generation for private investors, and the provision of service was a second priority. As stated in the beginning of this chapter, the response to the crisis was only a continuation of a neoliberal policy swing that began in the $1980 \mathrm{~s} .{ }^{187}$ While Portugal did intensify its privatization efforts during the crisis, it also divested from hundreds of state-owned companies during the 1990s. It is worth noting that Portugal only started to pursue privatization in a meaningful way after joining the EU in 1986. By 2014, many of the former state assets in Portugal were now generating profits for the

\footnotetext{
${ }^{185}$ Tsvetkov, Peter. "CTT, Annual Report 2014” Correios de Portugal. 2014 Web. 5 Apr. 2015: < http://www.ipc.be/ /media/Documents/PUBLIC/annual-reports/member-reports/2014/CTTCorreios\%202014.pdf>

${ }^{186}$ Almeida Henrique and Anabela Reis. "Portugal Agrees to Sell REN Stake for 592 Billion Euros." Bloomberg Business. 2 Feb. 2012. Web. 5 Apr. 2015. $<$ http://www.bloomberg.com/news/articles/2012-02-02/portugal-agrees-to-sell-ren-stake-for-592million-euros-1->

"Company Overview of REN - Redes Energéticas Nacionais, SGPS, S.A.” Bloomberg Snapshot. Bloomberg Business. 4 Apr. 2015 Web. 5 Apr. 2015. $<$ http://www.bloomberg.com/research/stocks/private/snapshot.asp?privcapId=5468837>

${ }^{187}$ Horn, 2012; International Labour Organization Executive 1 (2013 September 27): Personal Interview
} 
capitalist class. In contrast, private sector union membership declined from 1.9 million to 300,000 between 2008 and 2012 and unemployment remains stubbornly above 12 percent. $^{188}$

Similar trends are seen elsewhere in Europe. For example, France generated $€ 3.6$ billion from selling state assets between 2006 and 2012. However, from 1990 to 2010, the number of companies in which the French State was the majority shareholder decreased from 2779 to 946. ${ }^{189}$ In Italy, the Monti government announced in 2012 that they would generate $€ 16$ billion from privatization. However, this is in line with a long-term trend that began in Italy in the later half of the 1990s. ${ }^{190}$

Spain had a similar experience to Portugal during the crisis. In fact, with the exception of Greece, it may be the workers of the Iberian Peninsula that were most adversely affected by the crisis. Both the economy of Portugal and Spain were vulnerable before the crisis, and when the crisis began, both states turned to the Troika in order to meet the needs of capital, and in each country the working class was forced to bear the consequences of the crisis.

\section{Spain:}

The origins of the crisis in Spain can be traced back to the Franco years, when the country was controlled by a Fascist regime. Franco provided minimal public services and kept the tax burden on the population low. Like Portugal, Spain had not developed a technologically advanced manufacturing sector. The economy was based on small-medium scale manufacturing,

\footnotetext{
${ }^{188}$ Porter, Eduardo. "Americanized Labor Policy Is Spreading in Europe." The New York Times, December 3, 2013. http://www.nytimes.com/2013/12/04/business/economy/the-americanizationof-european-labor-policy.html?pagewanted=1\&_r=0\&adxnnl=1\&adxnnlx=1395961216sTUoDNAvRSH0YRQUwDP2XA (accessed March 21, 2014).: 1

${ }^{189}$ Brauninger, 2013, 4

${ }^{190}$ Brauninger, 2013, 6
} 
tourism and agriculture. ${ }^{191}$ Most trade unionists were killed or forced to flee the country when General Franco won the Spanish Civil War. Labour relations were then re-established on a fascist corporatist model in which dissent was quashed and loyalty to the state was rewarded. For that reason, Spanish workers have a long history of opposing capital through noninstitutionalized channels and without the support of the state. Furthermore, many are still suspicious of trade unions and see them as having little practical value in advancing the interests of workers. ${ }^{192}$

When Fascism finally came to an end in Spain, the people began to demand public services that were on par with the rest of Europe. The government did raise taxes to account for the new demands on the public purse, but the corruption that was commonplace in the Franco years still plagued the country. Indeed, tax evasion continued to be a major problem into the $21^{\text {st }}$ century. Consequently, Spain ran a continuous public deficit; a problem that was masked by economic growth that was spurred by new employment in the private sector and rapid growth in construction, real estate and tourism. ${ }^{193}$

As was the case in Ireland (and the United States), the crisis in Spain was primarily due to the highly risky and unsustainable practices that private banks were using to provide mortgages to the general public. This caused a boom in real estate and resulted in higher employment in the construction industry as depicted in Graphs 4.2. In order to finance these loans, Spanish banks had to borrow large sums on international markets, which tied the fate of the other European economies to the commercial success of Spanish Finance. The Spanish State also tied their fate to the success of the real estate market and designed their policy to benefit

\footnotetext{
${ }^{191}$ Banyuls, Josep and Albert Recio. "Spain: the Nightmare of Mediterranean Neoliberalism." A Triumph of Failed Ideas: European Models of Capitalism in the Crisis. ed. Steffen Lehndorff. Brussels: ETUI Print shop. 2013. 199-219.: 201

${ }^{192}$ European-level Labour Organization Representative 2(2013 November 12): Personal Interview

${ }^{193}$ Banyuls and Recio, 2012, 207
} 
from its growth. To that end, they had removed many of the taxes on the residential construction in order to encourage housing construction and then created new property taxes to offset the lost revenue. ${ }^{194}$

When mortgage delinquencies began to occur en masse, Spanish banks were forced to absorb a growing number of unpaid debts. As the defaults continued, property values crashed and it became clear that the banks were not going to be able to recover the lost revenue from reselling foreclosed homes. The financial sector began a sharp decline and massive layoffs occurred in the construction and real estate industries, which in turn led to more instances of mortgage delinquency. The construction industry alone accounted for more than a third of the layoffs in 2010, when the unemployment rate reached 21.3 percent. ${ }^{195}$ The situation was clearly worse for young people, with nearly half of people under 25 unable to find work. One trade unionist went as far as to say that European trade unions have completely failed young people in Southern Europe, and especially in Spain. ${ }^{196}$ The rise in unemployment only exacerbated the problems of the banking sector, which was now having difficulty meeting its obligations to foreign banks. Consequently, interest rates were raised on both Spanish banks and on state treasury bonds. Thus, as the pressure on state finances increased from the high interest rates, there was a simultaneous decline in the tax revenue garnered from property and income tax. ${ }^{197}$

\footnotetext{
${ }^{194}$ Banyuls and Recio, 2012, 209

${ }^{195}$ Josep Banyuls and Albert Recio, 2012, 206

${ }^{196}$ European-level Labour Organization Executive 1 (2013 September 26): Personal Interview

${ }^{197}$ Josep Banyuls and Albert Recio, 2012, 206, 208
} 
Graph 4.2: Spanish Employment by industry (thousands of employees) ${ }^{198}$

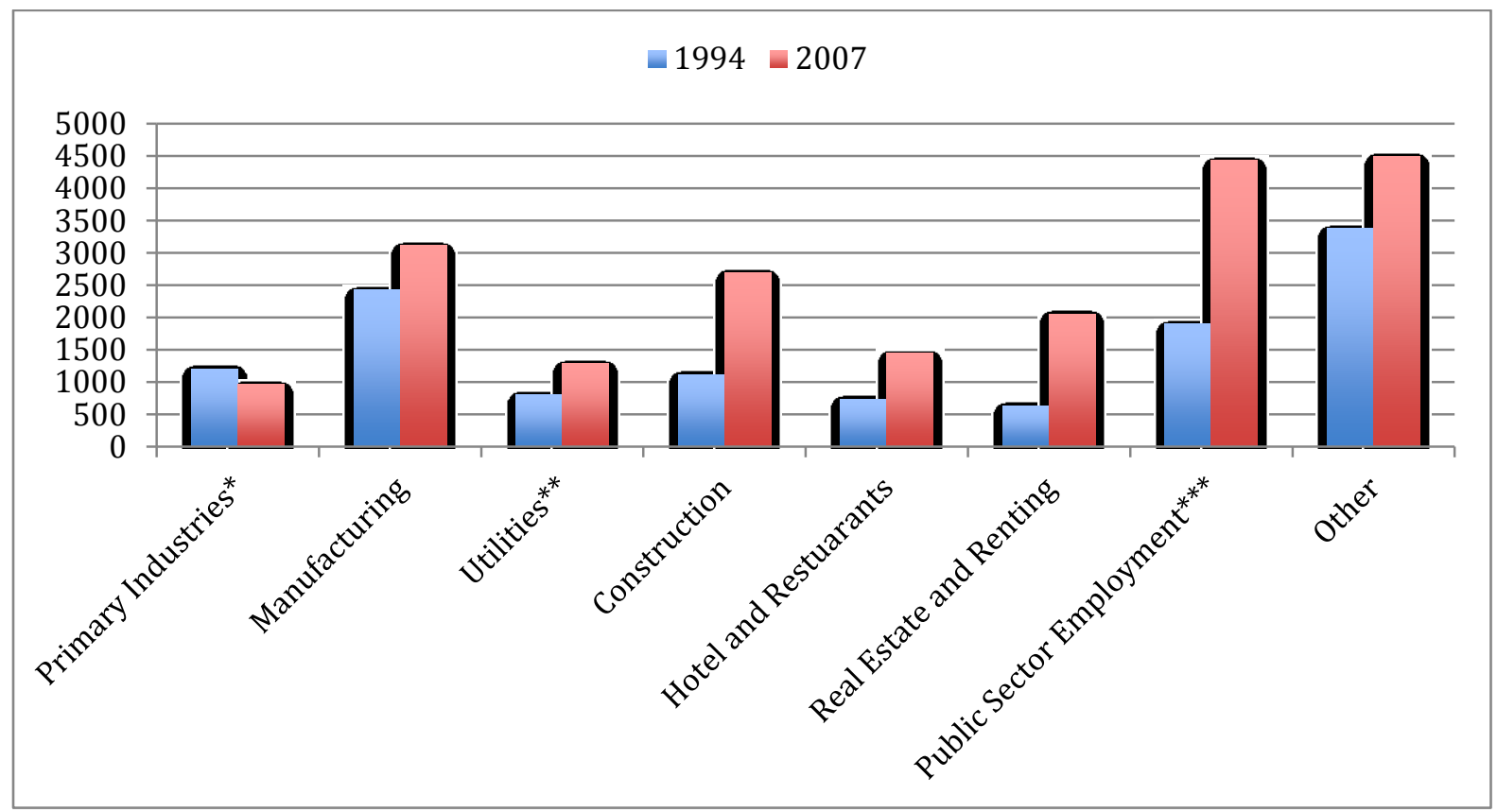

*Agriculture, fishing, forestry, mining, hunting and forestry

** Electricity, gas, water, transportation and communication

*** Public Administration, Defence, Social Security, Health, Social Work and Community Services

Several other Member States, especially Germany, held a great deal of debt from the Spanish private sector. If Spanish private banks had begun to fall, financial contagion would have been a considerable risk. For that reason, the EU and its Member States pressured Spain to support its financial sector and to get its public finances in line. More specifically, the Commission used the European Semester process to guide Spain's economic policy. ${ }^{199}$ The ideological foundation of the recommendations is clearly based in neoliberal policy. Below are excerpts taken from the country-specific recommendations for Spain in 2011 and the policies

\footnotetext{
${ }^{198}$ Banyuls, Josep and Albert Recio. "Spain: the Nightmare of Mediterranean Neoliberalism." A Triumph of Failed Ideas: European Models of Capitalism in the Crisis. ed. Steffen Lehndorff. Brussels: ETUI Print shop. 199-219.:203Ws

199 “The European Semester.” European Commission. European Union. 27 March. 2015. Web. 3 April 2015 from: http://ec.europa.eu/economy_finance/economic_governance/the_european_semester/index_en.ht $\mathrm{m}$
} 
that Spain delivered on in response. It is a clear example of the influence that the EU, and the financial sectors in the powerful Member States have over Spanish policy.

\section{Table 4.3: Spain's response to recommendations made via the European Semester}

The 2011 Council recommendation regarding collective bargaining and labour flexibility:

"...Spain needs to be complemented by an overhaul of the current unwieldy collective bargaining system... The automatic extension of collective agreements, the validity of non-renewed contracts and the use of ex-post indexation clauses contribute to wage-inertia, preventing the wage flexibility needed to speed up economic adjustment and restore competitiveness." 200

Action Taken by Spain on this portfolio ${ }^{201}$

- Legislate mandatory sunset clauses on all collective agreements

- Allow all firms to opt-out of sectorial collective agreements and to renegotiate them at the firm level

- Compensate 40 percent of the costs incurred by firms that engage in unfair dismissals. Reduce the compensation for unfair dismissal from 45 days to 33 days.

- Allowed firms to hire temporary workers on short-term contracts indefinitely.

The 2011 Council Recommendations on Pensions:

"The ... impact of ageing on the Spanish public budget is higher than the EU average. This is primarily because of the substantial increase in pension expenditure as a share of GDP that is projected for the coming decades... Pension reform, agreed with social partners, will improve fiscal stability and raise incentives for labour market participation."202

Action taken on this Portfolio: ${ }^{203}$

200 "COUNCIL RECOMMENDATIONS on Spain's 2011 National Reform Programme and Delivering a Council Opinion on Spain's Stability Programme for 2012-2015." European Commission. European Union, 30 May 2011. Web. 5 Apr. 2015.

$<$ http://ec.europa.eu/europe2020/pdf/recommendations_2011/csr_spain_en.pdf $>$., 4

${ }^{201}$ Josep Banyuls and Albert Recio, 2012, 211

${ }^{202}$ European Council (ES), 2011, 4

${ }^{203}$ Josep Banyuls and Albert Recio, 2012, 211 
- Increased the retirement age from 65 to 67 , early retirement option was increased from 61 to 63 years

- Expanded the years used to calculate pension benefit from 15 to 25 years.

Other drastic steps were taken to balance the budget on the back of the working class. Public sector wages were cut by five percent and responsibility for healthcare and education was relegated to regional governments who were not provided with adequate funding for the new responsibilities. Shockingly, in September 2011, a constitutional amendment was made which limited structural deficits to 0.4 percent of GDP. In addition, an unprecedented move was made to make payment of public debt the first priority of government spending part of constitutional law. By the end of the crisis, though the working class accounted for approximately half of the income generated in the country, they accounted for 80 percent of the revenue generated from income tax. ${ }^{204}$

In the Commissions Country Report for Spain 2015, it reported that the people of Spain are still suffering from the crisis and its response. In the first quarter of 2014, housing prices were only worth 36.2 percent of the value they held in the third quarter of 2007. Moreover, 12.6 million Spaniards (26 percent of the population) lived in poverty or endured social exclusion due to financial difficulty. Meanwhile, national debt has continued to rise and is predicted to reach 102.5 percent of GDP by $2016 .{ }^{205}$ Yet the Commission has continued to make country specific recommendations that are detrimental to the poor and the working class. These include the recommendation to "continue to increase cost effectiveness of the healthcare sector, in particular by further rationalizing pharmaceutical spending." ${ }^{206}$ Spain was also urged to "consider lowering

\footnotetext{
${ }^{204}$ Josep Banyuls and Albert Recio, 2012, 210

${ }^{205}$ European Commission (b). Country Specific Report 2015. Brussels: European Comission, 2015. 3-6

${ }^{206}$ Ibid, 70
} 
employers' social security contributions, in particular for low-wage jobs.”207 Lastely, Spain was instructed to "strengthen the job-search requirements in unemployment benefits... and [to] further measures to support labour mobility." 208

\section{The European level:}

The trends noted in the previous sections are not unique to the crisis countries. Since 2008, unemployment has increased in every EU country except Germany and Luxembourg. Between 2007 and 2012, only Bulgaria and the Netherlands recorded a growth in real wages greater than one percent. ${ }^{209}$ Likewise, over that time period only the Czech Republic experienced significant wage share growth. Wage share actually declined for workers in all but three countries and fell by more than two percent in 13 Member States. ${ }^{210}$ In contrast, between 2008 and 2014, the EU as a whole set aside a whopping $€ 3.89$ trillion to guarantee the liabilities of private financial institutions. In addition, they have authorized $€ 821.1$ billion for financial recapitalisation, of which 448 billion has been claimed. Private institutions also claimed an additional $€ 70.1$ billion of the $€ 379.9$ billion that is currently earmarked for liquidity support and $€ 188.2$ billion of the 669.1 billion that is set aside for asset relief. ${ }^{211}$

The financial sums that were used to support the needs of capital in the short- and medium-term are staggering. Perhaps more importantly though, during the crisis significant steps were taken to up-scale socioeconomic policy to the European Union and entrench long-term

\footnotetext{
${ }^{207}$ European Commission (b), 2015, 70-71

${ }^{208}$ Ibid, 72

${ }^{209}$ Benchmarking Working Europe 2013, 2014, 50

${ }^{210}$ Ibid, 52

211 "State Aid Scoreboard 2014 Aid in the Context of the Financial and Economic Crisis." European Commission. European Union, 17 Dec. 2014. Web. 7 Apr. 2015.

$<$ http://ec.europa.eu/competition/state_aid/scoreboard/financial_economic_crisis_aid_en.html >.
} 
advantages for the capitalist class. ${ }^{212}$ Nominally, socioeconomic and labour policy lay outside of the competencies of the European Union. However, in the Spring of 2010, the Member States and the EU adopted the Europe2020 strategy, which laid out the ten-year economic development plan of the Union. The pillar of Europe2020 was the use of the European Semester to monitor the economic progress of each Member States. ${ }^{213}$

The European Semester is an annual process that starts every year in October, when each Member States submits a draft budget to the Commission. In November, the Commission produces an opinion on each budget, which is provided to the European Council for review. In the same month, the Commission also produces an Annual Survey on Growth and the Alert Mechanism Report, which are both released publically. The former compares the annual growth rates of the Member States and the latter points to each State's macroeconomic imbalances that the Commission regards as problematic. In the months that follow, the Commission hosts bilateral meetings and conducts fact-finding missions with each Member States, and soon thereafter the Member States release their annual budgets along with their National Programmes, which detail how they plan to meet their obligations to the Union in concrete terms. In the next stage, in March the European Council uses the Annual Survey on Growth to set its economic priorities for the year. In May, the Commission produces country-specific recommendations (CSRs) to guide the budgetary, economic and social policies of each Member State. The CSRs are then put before the Council for review and adoption. ${ }^{214}$

The European Semester provided an avenue for the European Commission to directly influence the socioeconomic policies of Member States. It is clear that the vast majority of the

\footnotetext{
${ }^{212}$ International Labour Organization Representative 1(2013 October 26): Personal Interview; EU Employee 1 (2013 November 12): Personal Interview; MEP 2 (2013 November 12): Personal Interview

${ }^{213}$ European Commission (a) "Europe 2020." European Commission, 26 Feb. 2015. Web. 25 Apr. 2015. $<$ http://ec.europa.eu/europe2020/making-it-happen/index_en.htm>.l

${ }^{214}$ European Commission (a), 2015
} 
trade unionist interviewed felt that throughout the history of Europe2020 the Commission has used this avenue to forward distinctly neoliberal policies. ${ }^{215}$ Moreover, since its introduction agreements such as the Six-Pack, the Euro-Plus Pact and the Two-Pack have given the European Commission a more coercive power and have made the Semester process more obligatory for Member States. ${ }^{216}$ The Six-Pack was established in March, 2011 to enable the EU to monitor each progress of each Member State in addressing its national debt and deficit. It required each Member State to submit a medium-term objective (MTO) to the Commission that was designed to address national debt. It also established that the Commission had the power to enforce small sanctions against Member States should it not be satisfied with the progress that a Member States has made toward its MTO. The Commission even had the power to levy fines against Eurozone Member States. Though these fines were small, the fact that the Member States have given the an EU institution the power to sanction Member States outside of the judiciary is significant. ${ }^{217}$ In 2013, the Two-Pack added two regulations in order to further the progress made by the Six-Pack. The first of these regulations requires Member States to use an independent body to conduct its macroeconomic forecast as the foundation of its budget. It also empowers the Commission to demand a revised draft budget, should it not be satisfied with the a Member States draft submission in the European Semester. It also obliges Member States that have excessive debts or deficits to accept increased surveillance from the Commission and the European Central Bank. ${ }^{218}$

\footnotetext{
${ }^{215}$ MEP 2 (2013 November 12): Personal Interview; EP Employee 4 (2013 November 13): Personal Interview; International Labour Organization Executive 1 (2013 September 27): Personal Interview

${ }^{216}$ Eriksson, Jonas, and Monika Hjeds Lofmark. Crisis Management in the EU: Strengthening Economic Governance and Financial Stability. Stockholm: Swedish Institute for European Policy Studies, 2013. Print.

${ }^{217}$ European Commission. "Six-pack? Two-pack? Fiscal compact? A short guide to the new EU fiscal governance." Economic and Financial Affairs. http://ec.europa.eu/economy_finance/articles/governance/2012-03-14_six_pack_en.htm (accessed April 14, 2014).

${ }^{218}$ Ibid, 2014
} 
The Euro Plus Pact is an intergovernmental initiative that was signed by 23 of the 27 Member States. It required that each of the signatories take steps to enshrine the objectives of the Stability and Growth Pact into national law. Namely, those objectives are to a) improve the sustainability of public finance, b) to provide security for private investment c) to increase employment and d) to increase economic competitiveness. The Pact also requires that each of the signatories submit a progress report on these objectives every year in the European Semester schedule. ${ }^{219}$ The pact also names a policy set that is clearly neoliberal in nature as the way in which the Member States should pursue these objectives. For example, it specifically names sustained wage increases as a factor that may lead to the deterioration of competitiveness. It recommends that should the unit cost of labour increase rapidly, that the Member States should consider reviewing wage setting arrangements and indexation mechanisms and where applicable, consider decentralizing bargaining processes. It also recommends taking steps to promote flexicurity in the labour market and to align public sector wages with those in the private sector. $^{220}$

The Treaty on Stability, Coordination and Governance in the Economic and Monetary Union (the Fiscal Compact), was yet another intergovernmental treaty that was signed on March $2^{\text {nd }}, 2012$ by all members of the European Union except the Czech Republic and the United Kingdom. It established that each Member State should enact national laws that prevented government from having a structural deficit that exceeded 0.5 percent of GDP. Further, that each Member State was required to create an automatic correction mechanism that would be utilized should the structural deficit exceed the limit and the state government failed to take steps to

\footnotetext{
${ }^{219}$ Eriksson and Lofmark, 2013, 4

${ }^{220}$ Moussis, Nicholas. "Europedia - The Euro Plus Pact." Europedia. European Study Service, 2011. Web. 25 Apr. 2015. <http://www.europedia.moussis.eu/discus/discus-1241513297-44891132221.tkl>.
} 
correct it. It also enabled the European Court of Justice to levy a fine not exceeding 0.1 percent of GDP should another Member State prove that another failed to entrench a sufficient correction mechanism into national law. It also created the European Stability Mechanism (ESM) to replace the ESFS and the ESFM. According to this treaty, a Member State could not access a bailout after 2012 if it had not signed the Fiscal Compact. ${ }^{221}$

${ }^{221}$ Dullien, Sebastian. "Reinventing Europe: Explaining the Fiscal Compact." European Council on Foreign Relations. European Council on Foreign Relations, 1 May 2012. Web. 26 Apr. 2015. $<$ http://www.ecfr.eu/article/commentary_reinventing_europe_explaining_the_fiscal_compact $>$. 


\section{Section 4.3: The Response of Organized Labour}

Every participant felt that the European labour movement has and continues to be the most effective in the advanced capitalist world. ${ }^{222}$ At both the national and transnational level, European labour has achieved a level of institutional influence that is unrivalled, and the ability of European workers is likely unmatched by any other transnational workers movement in the world. At the national level, labour representation has been built into various state institutions across the continent and unions have been historically regarded as important stewards of the welfare state in most European countries. Transnationally, they have managed to secure several institutional avenues for representation within the EU. ${ }^{223}$ Unions have also displayed a relatively impressive ability to mobilize, and have held general strikes in Greece, France, Ireland, Italy, Portugal and Spain. ${ }^{224}$ They have also had some success in constructing transnational solidarity. As noted previously, 92 percent of national-level labour organizations report sharing information with their counterparts in other countries to help inform their collective bargaining strategies. Moreover, more than half of the trade unions in Europe take place in some type of transnational action at least once a year. $^{225}$

The historical result of their efforts attests to their abilities. While the working class has endured several defeats since the Single European Act was signed in 1992, these defeats happened in the context of a global neoliberal policy shift. In comparison to North America and elsewhere in the world, Europeans have been very effective in preserving the welfare state and

\footnotetext{
${ }^{222}$ European-level Labour Organization Executive 2 (2013 September 26): Personal Interview

${ }^{223}$ Greenwood, Justin. Interest representation in the European Union. Houndmills, Basingstoke, Hampshire: Palgrave Macmillan, 2011.

${ }^{224}$ Horn, 2012, 585

${ }^{225}$ Larsson, B. (2012). Obstacles to transnational Trade Union Cooperation in Europe - Results from a European Survey. Industrial Relations Journal. 43(2). 152-170: 159
} 
pushing back against attacks on labour rights. ${ }^{226}$ The affordability of post-secondary education in Europe is an example of the robust nature of the welfare state in Europe, and the EU-mandated minimum of 20 paid vacation days is something that trade unions in North America have yet to achieve, even on state or provincial levels. ${ }^{227}$

However, while noting the validity in those observations, only two research participants engaged in such an analysis without being prompted. They instead seemed to prefer a temporal comparative evaluation and tended to describe the current character of industrial relations and socioeconomic context in relation to those to the recollections of past and assumptions about the future. ${ }^{228}$ With that frame of reference in mind, when asked flatly if the European labour movement had been successful during Eurozone Crisis, only one of 31 people interviewed stated that they he believed that the labour movement had been sufficiently successful. It is noteworthy, that he was not a trade unionist, but a representative of an employers' organization. ${ }^{229}$

The next two sections provide an analysis of the structural and institutional power of labour in the context of the Eurozone Crisis. While these sections are primarily based on opinions rather than fact, it is important to note that the opinions represented were widely shared by the participants. Moreover, the viability of their opinions and perspectives is supported by the policy and political developments that took place throughout the crisis itself.

\footnotetext{
${ }^{226}$ European-level Labour Organization Executive 1 (2013 September 26): Personal Interview; Europeanlevel Labour Organization Executive 2 (2013 September 26): Personal Interview 227 "Survey - Paid Vacations \& Holidays in OECD Countries - Radius." Survey - Paid Vacations \&amp; Holidays in OECD Countries - Radius. Centre for Economic Policy Research, 18 June 2013. Web. 9 Apr. 2015.

${ }^{228}$ National Labour Organization Representative 5 (2013 November 20): Personal Interview; ational Labour Organization Executive 1 (2013 November 13): Personal Interview; National Labour Organization Representative 7 (2013 November 22): Personal Interview

${ }^{229}$ Transnational Employer Organization 1 (2013 November 15): Personal Interview
} 


\section{Structural Power:}

There are several factors that have limited the structural capabilities of organized labour. The labour movement has yet to construct consistent and meaningful transnational solidarity among the rank and file. Several research participants stated that workers were more likely to see their counterparts in other countries as competitors than as potential allies. ${ }^{230}$ There is also a notable disconnect between rank and file union members and trade union secretariats. One participant even claimed that union employees are often regarded as 'parasites' by both member and non-member workers. ${ }^{231}$ Another participant also noted that there is often animosity between private and public sector workers, which sometimes translates into tensions between their respective unions. Due to the fact that tax revenue pays for the labour of public servants, they are often portrayed as having contradictory interests to those of the taxpayers - or private sector workers. Public servants are characterized as 'greedy and lazy', and as their salary and benefits are afforded by public expenditure, they are often described as perpetuators and/or a primary cause of the crisis. This is especially true when austerity measures were being aimed at the pay and benefits of public servants. ${ }^{232}$ Lastly, many participants noted that trade unions have only just begun to build on their efforts to connect with unorganized workers and non-labour civil society organizations. ${ }^{233}$

Perhaps the most limiting factor in building solidarity is the lack of a common identity amongst the European working class. As outlined in Chapter 2, perceptions of identity determine the ability of the working class to build and maintain solidarity. Further, that identity is defined

\footnotetext{
${ }^{230}$ European-level Labour Organization Executive 1 (2013 September 26): Personal Interview; National Labour Organization Representative 7 (2013 November 22): Personal Interview

${ }^{231}$ National Labour Organization Representative 4 (2013 November 22): Personal Interview

${ }^{232}$ European-level Labour Organization Representative 2 (2013 November 12): Personal Interview

${ }^{233}$ European-level Labour Organization Representative 2 (2013 November 12): Personal Interview
} 
and perpetuated by social constructions of space and by shared experiences. ${ }^{234}$ It is not that individuals do not identify as the 'European working class', it is that this identity is obscured by, and secondary to, identities based on nationality on the one hand and by identities based on factors related to the nature of one's employment, ethnicity and social status. ${ }^{235}$ While workers do identify as Europeans, national identities based on the national territoriality and culture and influenced by uneven spatial development are more deeply engrained into the European disposition. ${ }^{236}$ Likewise, it is not that individuals do not identify as workers, it is that they are more likely to identify themselves based on their sector of employment or as being full-time, part-time, or unemployed. ${ }^{237}$

With regards to spatially-defined identity, it is only in the past generation that labour relations have truly been up-scaled to the transnational level and only in the past twenty years that the EU has taken a significant role in industrial relations. Moreover, it is only in the countries where the EU institutions have played a major role in dictating austerity that workers have consistently organized in relation to the EU. ${ }^{238}$ In many countries it is more likely that the workers feel that they have more in common with a capitalist with whom they share a nationality with, than they do with a worker from another country. ${ }^{239}$ In that regard, one Member of the European Parliament who participated as an interviewee stated the following:

"The European people are not a people. Perhaps you can talk about a 'Chinese' or an 'American' people, but definitely not a European people. The discussion in

\footnotetext{
${ }^{234}$ Polanyi, Karl. The Great Transformation. [1st Beacon paperback ed. Boston: Beacon Press, 1944. Patel, Rajeev. "International Agrarian Restructure and the Practical Ethics of Peasant Movement Solidarity." Journal of Asian and African Studies 41, no. 1-2 (2006): 71-93.

${ }^{235}$ European-level Labour Organization Executive 2 (2013 September 26): Personal Interview

${ }^{236}$ National Labour Representative 1(2013 October 30): Personal Interview; National Labour Organization Representative 9 (2013 November 22): Personal Interview

${ }^{237}$ National Labour Organization Executive 2 (2013 December 3): Personal Interview

${ }^{238}$ EU Employee 1 (2013 November 12): Personal Interview; EP Employee 2 (2013 November 12): Personal Interview

${ }^{239}$ European-level Labour Organization Executive 4 (2013 November 21): Personal Interview
} 
Denmark has nothing to do with the discussion in Greece; Austria has nothing to do with the discussion in Spain." 240

In the context of the crisis, it has been difficult to build transnational solidarity in opposition to transnational neoliberalism because it is experienced differently in each country. As stated above, Denmark has not had the same experience as Greece, nor has Austria had the same experience as Spain. In spite of the fact that in every country, the working class has experienced political disenfranchisement at the European-level, increased intra-class competition caused by social dumping, exacerbated international and domestic socioeconomic inequality and the dismantlement of the welfare state, the European labour movement has failed to construct a discourse that is built on the shared experience of the working class. Thus, it has been unable to build and sustain ongoing solidarity or pressure at the EU-level.

Another significant weakness of the labour movement is the deafening absence of a congruent policy alternative to neoliberalism. One participant named this as a serious issue that "saps energy out of mobilization efforts". ${ }^{241}$ There are several interconnected factors that have prevented labour organizations from presenting an alternative. Firstly, labour organizations have had a great deal of difficulty communicating their support for the concept of the European Union/European integration on the one hand, an opposition to neoliberalism on the other. ${ }^{242}$ It is clear that capital operates transnationally and accordingly that the working class must be equally capable of operating at that level in order to nullify or at least mitigate the advantages that capital gains from its transnational mobility. To that end, the vast majority of trade unions are generally

\footnotetext{
${ }^{240}$ MEP 2 (2013 November 12): Personal Interview

${ }^{241}$ National Labour Representative 1(2013 October 30): Personal Interview; European-level Labour Organization Representative 2(2013 November 12): Personal Interview; International Labour Organization Representative 1(2013 October 26): Personal Interview

${ }^{242}$ National Labour Representative 1(2013 October 30): Personal Interview
} 
in favour of greater European integration. ${ }^{243}$ However, it is also clear that neoliberalism has been built into the treaties of the EU and has clearly been a source of hardship for European workers. ${ }^{244}$ It is therefore difficult to reconcile the support for greater European integration with trade union opposition to several of the fundamental tenants of the European Union. In voicing support for the EU, they de facto also voice support for neoliberal policy. When they do oppose the EU, their opponents often characterize them as anti-European extremists. ${ }^{245}$ However, it is clear that the labour movement has yet to fully buy into an alternative policy set to neoliberalism. As stated by one Dutch participant:

The ETUC, the IMF, and the OECD have made reports saying that austerity is not working. But the politicians (in the EU) believe in the policies of internal deflation, we are unable to challenge them... One of the reasons is that we don't have an alternative. We believe in greater European coordination, but that goes against the instincts of every country in crisis times, the first priority is the national level.

The 'Dutch are against general statements' they don't want to say 'we are against this', if there is no alternative'. If you can't make your alternative clear, then just keep your mouth shut. ... If you're in Spain, where there is no form of bargaining or communication between unions and the government, you are much more likely to make statements like 'we're not going to take it any more' and go on strike. We won't do that, it is unheard of in the Netherlands. ${ }^{246}$

As described in this quote, the necessity of an alternative to austerity cannot be understated. The participant went on to explain that historically, the European labour movement has had greater success when it is mobilizing for a solution rather than against a problem. The

\footnotetext{
${ }^{243}$ International Labour Organization Executive 1 (2013 September 27): Personal Interview

${ }^{244}$ Wahl, 2014, 5

${ }^{245}$ EU Employee 1 (2013 November 12): Personal Interview

${ }^{246}$ National Labour Representative 1 (30 October 2013): Personal Interview
} 
inability to advocate an alternative has seen labour organizations pushed to the edges of policy making circles at both the European and national levels. ${ }^{247}$

Lastly, labour organizations still prefer to work in relation to national governments rather than the European Union. In a practical sense, this may be due to the fact that labour organizations often have long histories working at the national level and very few even have offices in Brussels. When they do, the offices very rarely consist of more than a handful of staff. $^{248}$ Moreover, nation-based organizations were caught off guard by the role that the EU began to play in the Eurozone crisis. Many described the EU as becoming suddenly undemocratic and coercive in relation to its advocacy in the case of industrial relations and socioeconomic policy. ${ }^{249}$ However, in northern Europe, the story was rather different. The crisis has yet to have a significant or direct impact on the standards of living or working conditions in many of those countries. Thus the EU continues to be somewhat abstract and their labour organizations have yet to seriously make efforts to mobilize at the European level. ${ }^{250}$ When a Scandinavian participant was asked if he believed Scandinavian unionists feel involved or committed to the fight against EU austerity, he responded “it doesn't even feel like a fight at all. ${ }^{, 251}$

\section{Institutional Power:}

Over the course of the 1990s, the ETUC had lent its support to the creation of a single European market in exchange for institutional power in the form of representation in the

\footnotetext{
${ }^{247}$ International Labour Organization Executive 1 (2013 September 27): Personal Interview

${ }^{248}$ National Labour Organization Representative 5 (2013 November 20): Personal Interview

${ }^{249}$ MEP 2 (2013 November 12): Personal Interview

${ }^{250}$ EU Employee 1 (2013 November 12): Personal Interview

${ }^{251}$ EP Employee 2 (2013 November 12): Personal Interview
} 
European Employment Strategy, the European Economic and Social Committee, and of course in the European Social Dialogue. These institutions became the foundation of its strategy to represent the needs of European workers. Unfortunately, these institutions were completely sidelined during the response to the crisis. Moreover, the ESFS (which later was replaced by the European Stability Mechanism), and the European Semester allowed the Commission to influence socioeconomic policy without the input of the European Parliament, and the allies of the labour movement therein. ${ }^{252}$ The labour movement soon found that the Commission almost completely ignored the input from labour while prioritizing the needs of the financial sector. ${ }^{253}$ As pointed out by one participant who was the former Secretary General of one of the largest labour organizations in the world:

The Commission completely oversteps its bounds, it is not supposed to comment on remuneration or pensions, but it does, and the parliament is silent, completely silent. The parliament was also silent/excluded from debate on the Six-Pack, and the Two-Pack. ${ }^{254}$

The silence of the EP on the Six-Pack and Two-Pack as it gave the Commission a much greater role in influencing the budgets of the Member States. Both of the Packs were designed to give the Commission greater power to force the Member States to respect the obligations of Stability and Growth Pact (SGP); namely, the obligation to keep public debt below 60 percent of GDP and to ensure that government deficits do not exceed three percent. The Six-Pack established that each Member State was obligated to submit a medium-term objective (MTO) that was designed to address national debt. It also gave the Commission the power to enact fiscal sanctions against Member States, including fines within the Eurozone, if they were not satisfied

\footnotetext{
${ }^{252}$ National Labour Organization Representative 5 (2013 November 20): Personal Interview

${ }^{253}$ International Labour Organization Executive 1 (2013 September 27): Personal Interview; International Labour Organization Representative 3 (2013 November 22): Personal Interview

${ }^{254}$ International Labour Organization Executive 1 (2013 September 27): Personal Interview
} 
that the member at had made significant progress towards its MTO it its national budget. What's more, is the only way that a sanction could be overturned is if a qualified majority of Member States voted to overturn the sanction. The Six-Pack also requires the Member States to enshrine their MTOs, which are negotiated with the Commission, into national law ${ }^{255}$ The Two-Pack requires Member States to provide a draft of their national budgets to the Commission by midOctober. In addition it provides the Commission the discretion to evaluate the budget and require that Member States submit a revised budget if the Commission feels that they Member State is not meeting its obligations of the SGP. The Commission lists the two of the benefits of the TwoPact as follows:

National Parliaments... would now be equipped with an independent opinion on the budgetary plans, namely the Commission opinion.

The Regulation (the Two-Pact) ensures appropriate integration of EU policy recommendations in the national budgetary preparations and increasing peer pressure in the Euro Group. ${ }^{256}$

Thus the explicit goal of the Two-Pact was to pressure Member States into adopting the recommendations of the Commission into their national budgets. This is why European labour organizations were stunned when the Commission simply began to ignore the input they put forward in the EESC in addition to stalling framework agreements that were put forward by the Social dialogue indefinitely. ${ }^{257}$ One labour leader pointed out that the policies of the Commission are nearly identical to the recommendations of EESC Group I (employer organizations), and that

\footnotetext{
${ }^{255}$ European Commission. "Six-pack? Two-pack? Fiscal compact? A short guide to the new EU fiscal governance." Economic and Financial Affairs. http://ec.europa.eu/economy_finance/articles/governance/2012-03-14_six_pack_en.htm (accessed April 14, 2014).

${ }^{256}$ European Commission, 2012

${ }^{257}$ International Labour Organization Executive 1 (2013 September 27): Personal Interview
} 
the recommendations of Group II (trade unions) are nearly completely ignored. ${ }^{258}$ She went further to say that increasingly trade unions are being pushed out of policy circles in Brussels. She pointed to the creation of the Tax Evasion and Avoidance Task Force as an example. She claims that the ETUC and its partners put forward five trade union candidates for the task force, yet only one was selected. In contrast, eight representatives of BusinessEurope were selected. ${ }^{259}$

Many trade unionists believe that the ETUC and the labour movement have become too dependent on EU institutions and were too slow to mount opposition to the EU. However, it is important to note that the ETUC is a confederation consisting of 90 organizations from 39 countries. ${ }^{260}$ While opposition from the ETUC has been slow, the pluralistic nature of the ETUC has slowed its ability to respond effectively. However, as the crisis carried on the ETUC did become increasingly critical of the European Union. ${ }^{261}$ It has only been since the Laval, Viking and the Rüffert cases in 2005 and 2006 that most labour organizations truly began to recognize the prioritization of capital in the EU judicial system. Furthermore, it has only been in the context of the crisis itself, that labour has seen the Euro and the role of the ECB used as a tool to force down the costs of labour, the European Parliament being excluded from the European Semester protocols and the European Commission completely ignoring the framework agreements produced by the European Social Dialogue. ${ }^{262}$

Nonetheless, while opposition was building within the ETUC, the long-term trend of trade union marginalization continued. In the interviews, several trade unionists spontaneously suggested that the EU is slowly moving towards a "British" or "American" Anglo-Saxton' style

\footnotetext{
${ }^{258}$ National Labour Organization Representative 5 (2013 November 20): Personal Interview

${ }^{259}$ National Labour Organization Representative 5 (2013 November 20): Personal Interview

260 "European Trade Union Confederation." Composition and Organization. European Trade Union Confederation. Web. 12 Apr. 2015. <http://www.etuc.org/composition-and-organisation>.

${ }^{261}$ International Labour Organization Executive 1 (2013 September 27): Personal Interview

${ }^{262}$ MEP 2 (2013 November 12): Personal Interview; National Labour Organization Representative 5 (2013 November 20): Personal Interview
} 
of labour representation, where there is no longer an automatic or systemic way to include trade unions in policy discussions. ${ }^{263}$ One unionist claimed that even the allies of labour sometimes forget to include unions in relevant policy decisions. She pointed out that it is undemocratic to exclude trade unions, as they represent the interests of more Europeans than any other organizations in Brussels outside of the EU institutions themselves. ${ }^{264}$ However, across the EU, popular discourse often describes unions in a negative light and for various reasons, many workers do not identify with trade unions or as trade unionists. On one side of the spectrum, unions are often regarded as being unrealistic and out of touch at best, or at worst as perpetuators/causes of the crisis itself. ${ }^{265}$ On the other hand, new social movements often regard unions to be the extensions of the state that limit the disruptiveness of protests, manufacture consent and legitimize the attacks on the working class. ${ }^{266}$ In addition, trade unions supporters also lose enthusiasm due to the fact that absence of a credible alternative policy set also limited the influence of trade unions in these institutions. ${ }^{267}$ These limiting factors create space for policy makers to avoid the pressure of unions. In contrast, most policy makers are under the impression that in ignoring or pushing back against the position of capital, that they risk limiting production and causing greater hardship for the people of Europe.

One prominent trade unionist hypothesized that labour organizations, especially those at the European-level, are aware of their limited capacity to effect change and have adjusted their strategies accordingly. No longer are they pursuing victory, they have now resorted to mitigating defeats. For example, one trade unionist noted that the European Public Sector Union is put in a

\footnotetext{
${ }^{263}$ National Labour Organization Representative 5 (2013 November 20): Personal Interview; Europeanlevel Labour Organization Executive 1 (2013 September 26): Personal Interview

${ }^{264}$ National Labour Organization Representative 5 (2013 November 20): Personal Interview

${ }^{265}$ International Labour Organization Representative 1(2013 October 26): Personal Interview

${ }^{266}$ National Labour Organization Executive 1 (2013 November 13): Personal Interview

${ }^{267}$ National Labour Representative 1(2013 October 30): Personal Interview
} 
position where they have are negotiating the downsizing of the public sector. ${ }^{268}$ Likewise, former ETUC General Secretary, John Monks, actually endorsed flexicurity, and signed a joint statement with BusinessEurope calling for the restraint of non-wage labour costs in order to lower the costs of labour and create more jobs. The same statement also called for the use of "well-balanced public-private partnerships" to provide more efficient and effective public services. ${ }^{269}$ The same trade unionist also stated that:

The unions are defeated everywhere, the elites do not fear the trade unions, they are glad as long as the unions beg for a seat at the table. The elites have always been very clever with lip service; 'we are going to create a social Europe, etc.'

Now some of them are feeling so strong, so confident that they say things like 'we are coming to the end of the welfare state' and it's correct, they are strong. The resistance from the labour movement is not there. ${ }^{270}$

\footnotetext{
${ }^{268}$ European-level Labour Organization Representative 2(2013 November 12): Personal Interview

${ }^{269}$ Wahl, 2014, 10

${ }^{270}$ International Labour Organization Executive 1 (2013 September 27): Personal Interview
} 


\section{Section 4.4: The Counterweight, Building new Alliances}

It is clear that the deterioration of the structural power of trade unions has had a negative influence on their institutional capabilities. In an attempt to reverse that trend many trade unions have built partnerships with non-union social movements with varying degrees of success. The ETUC in particular, has been incorporating intersectional alliances into their strategies for quite some time. During the 1990s, The ETUC cooperated with women's organizations to help forward gender equality in the work place across Europe and it has also worked with environmental organizations to ensure that both environmental and union priorities were incorporated into the EU's definitions of 'sustainable production' and 'sustainability'. ${ }^{271}$

In context of the crisis, the ETUC also attended and contributed funding to the Alter Summit. The Summit brought over 200 civil society organizations, NGOs, trade unions, and feminist organizations together from across Europe with the objective of organizing panEuropean resistance to austerity. In order to quell opposition from social movements that were suspicious of trade unions, the ETUC voluntarily offered to participate as an observer rather than a full participant. The ETUC played a central role not only in funding the Summit, but also in helping other participants identify political pressure points for social action and in connecting them with representatives of ETUC member-organizations in different localities across the continent. ${ }^{272}$ According to one labour leader, the AlterSummit produced notable instances of resistance; it was the birthplace of the Blockupy Movement, which blocked entry during the grand opening of the ECB's new building in Frankfurt in 2015. ${ }^{273}$ Moreover, it contributed to the

\footnotetext{
${ }^{271}$ National Labour Organization Representative 5 (2013 November 20): Personal Interview

${ }^{272}$ National Labour Organization Executive 1 (2013 November 13): Personal Interview; EU Employee 1 (2013 November 12): Personal Interview

${ }^{273}$ National Labour Organization Executive 1 (2013 November 13): Personal Interview
} 
organization and advancement of Social Democratic parties and far leftist groups in the 2014 European elections. $^{274}$

This strategy has contributed to the construction of a social movement that extends past 'union' issue to working class issues. The Alter Summit, and groups like it, involves groups that focus on a myriad of social issues and specifically names 'neoliberalism' as the target. ${ }^{275}$ Rather than identifying a 'symptom' as a common experience, the discourse forwarded at the AlterSummit identified the neoliberal ideology, the cause of the symptoms, as the common experience. This allows for a common identity, a collective, to be built on a multi-scalar dimension that extended from the local to the transnational. While organizations like the AlterSummit present a viable way forward for trade unions, there are still historical and cultural barriers that they will have to overcome, especially in Southern Europe.

In Greece for example, over 95 percent of the population believes that unions did "nothing or very little" to resist austerity during the Eurozone crisis. ${ }^{276}$ In Greece, the government recognizes two union confederations as the national voices of labour, the Civil Servants' Confederation, ADEDY, represents public sector workers and the Greek General Confederation of Trade Unions, GSEE, is a conglomerate of private sector unions. Traditionally, ADEDY is much less political than the GSEE, and has usually simply followed the lead of the GSEE when it comes to engaging in social action. ${ }^{277}$ The GSEE is a confederation of trade unions which are each given a number of seats on the GSEE's governing body (the Administrative Board) that is relative to the number of workers it represents. The reason the population is suspicious of the GSEE is that each of the vast majority of its affiliates have formal

\footnotetext{
${ }^{274}$ National Labour Organization Executive 1 (2013 November 13): Personal Interview

${ }^{275}$ National Labour Organization Executive 1 (2013 November 13): Personal Interview

${ }^{276}$ Vogiatozoglou, 2015, 5

${ }^{277}$ Vogiatzoglou, Markos. Trade Unions in Greece: Protest and Social Movements in the Context of Austerity Politics. 2014. San Demenico di Fiesole, Italy: European University Institute. 2
} 
affiliations to political parties. As illustrated in Graph 4.4, unions that directly support the two main political parties, both of which instituted harsh austerity measures, control 30 of the 45 seats on the Administrative Board. ${ }^{278}$ This has deeply tarnished the image of the GSEE in the eyes of the Greek people. ${ }^{279}$ Two different participants claimed that the goal of the thirty ${ }^{280} 24$ hour general strikes organized by the GSEE was not to apply pressure on the government, but to preserve the legitimacy of the GSEE and to allow workers to vent frustration while limiting the possibility of further action. ${ }^{281}$ Even though GSEE had organized over fifty 24 hour general strikes, "95.2 percent of [Greek] respondents considered that unions did "very few things or nothing" to block austerity" in $2014 .^{282}$

\footnotetext{
${ }^{278}$ Vogiatzoglou, 2014, 3

${ }^{279}$ EC Employee 4 (2013 December 2): Personal Interview

${ }^{280}$ As of the Winter 2014, there had been at least fifty general strikes

${ }^{281}$ EC Employee 4 (2013 December 2): Personal Interview; International Labour Organization Executive 1 (2013 September 27): Personal Interview

${ }^{282}$ Vogiatozoglou, 2015, 5
} 


\section{Graph 4.4 Distributions of Seats in the GSEE Administrative Board}

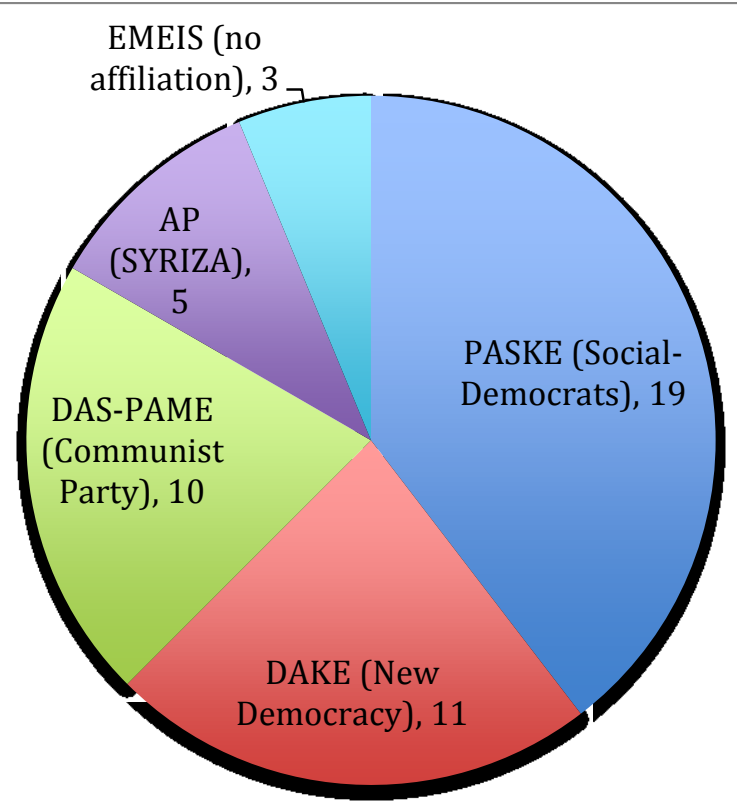

In Spain, trade unions have also been excluded from social demonstrations by new social movements. On May 15, 2011, a string of protests were launched across Spain by a group of primarily young people called the Indignados (The Outraged). This group is also known as the Spanish Anti-Austerity Movement, or the 15-M Movement. Drawing on imagery from the Arab Spring, the Indignados utilized a discourse that explicitly opposed a system that allowed a hegemonic class to control capital and public policy. Their protest action was aimed against the support the government was lending to the financial sector in juxtaposition with the imposition of austerity on the working class. ${ }^{283}$ Interestingly, unions were regarded to be part of the system that was oppressing workers. On the unions in Spain, one trade union general secretary stated:

${ }^{283}$ European-level Labour Organization Executive 4 (2013 November 21): Personal Interview 
Yes, and in some countries, unions are seen as part of the problem. When you look at the Indignados, when they were gathering in the main squares in the Madrid, you could not mention that you were part of a trade union. For too many years the two biggest trade unions in Spain have been signing agreements that cut rights and wages for young workers. ${ }^{284}$

Both in the case of Greece and of Spain, social movements managed to change the political landscape of the country. Recently in Greece, the self-discribed radically-left SYRIZA Party managed to win the general election. In Spain, Podemos, also a radical-leftist party, shot up to lead the polls in its first year of existence. ${ }^{285}$ Part of the reason that these social movements and political parties have enjoyed success is that they represent an alternative to neoliberal politics.

\footnotetext{
${ }^{284}$ National Labour Organization Executive 1 (2013 November 13): Personal Interview

${ }^{285}$ Comas, Andrea. "Spain's Anti-austerity Podemos Neck-to-neck with Mainstream Parties: Poll." Reuters. Thomson Reuters, 12 Apr. 2015. Web. 12 Apr. 2015. $<$ http://www.reuters.com/article/2015/04/12/us-spain-poll-idUSKBN0N30C220150412>.
} 


\section{Chapter 5: Conclusion}

The purpose of this thesis was to assess why the European labour movement had been unsuccessful in forwarding the interests of the working class during the Eurozone crisis. As shown throughout, the answer is multifaceted. However at the core of the struggles of organized labour was its relative inability to operate at the European-level. This thesis has clearly illustrated that the institutions of the European Union have major and direct impacts on social policy, labour rights and the overall political objectives of its Member States.

Before going further, it is useful to review the theoretical foundations of the thesis. As

originally noted by Karl Marx, the struggle between the capitalist and working classes is defining feature of the capitalist mode of production. As such, the concept of class was used as the point of departure for this thesis. The thesis goes on to say that the role of the state in the capitalist mode of production is to facilitate and enforce a class compromise according to the relative power of the two classes with the objective of maximizing the societal accumulation of capital. The state then, should not be thought of as an actor in its own right, but as a matrix of institutions that host the political interactions of society. The thesis leans heavily on the work of Laura Horn, who defines two different interconnected avenues through which the two classes gain the ability to influence the state and interact through its mechanisms. The first, structural power, is derived from the capacity of either class to disrupt the production process. The second, institutional power, refers from the power either class gains from formal forms of representation, which are usually housed within the mechanisms of the state. Uneven Spatial Development theory is used to examine the multi-scalar interaction of capital and labour, allowing us to see the advantage that capital has gained from operating on the transnational scale as opposed to labour whose representation by and large remains either on the national level or has even been decentralized to 
subnational levels. These concepts provide the theoretical foundation that enables the examination of the Eurozone Crisis.

The causes and outcomes of the Eurozone Crisis are well documented and vary from country to country. However, there were common features in every case. First, that in each country, the financial sector played a major role in instigating the crisis. Further, the response to the crisis was either dictated, or closely guided by the EU (often in collaboration with the IMF). In every country, the EU pushed for a strictly neoliberal crisis response explicitly designed to support the needs of capital, erode the socioeconomic security of workers and lowered the unit cost of labour by dismantling social services. ${ }^{286}$ It is again worth emphasizing that the European labour movement is perhaps the most effective in the world and it is impossible to know how much further austerity could have gone if they had been less effective. Additionally, the participants unanimously agreed it is clear that the labour movement had clearly been losing ground to capital before the crisis began. Likewise, the EU's blatant support for capital while Europeans were enduring austerity speaks to the relative weakness of organized labour in relation to capital. ${ }^{287}$

The Participants agreed that the current challenges that face the labour movement developed over the past 30 years, as neoliberal principles were continually engrained into the developing structure of the European Union. ${ }^{288}$ During this time period, the treaties of the EU continually subjugated social interests to the interests of capital and obliged EU member states to abide by neoliberal economic principles. As one trade unionist said, “... The European Union

\footnotetext{
${ }^{286}$ Benchmarking working Europe. Brussels: ETUI-REHS, 2013.: 50

${ }^{287}$ National Labour Representative 1(2013, October 30): Personal Interview; International Labour Organization Executive 1 (2013 September 27): Personal Interview; European-level Labour Organization Executive 1 (2013 September 26): Personal Interview; European-level Labour Organization Executive 2 (2013 September 26): Personal Interview

${ }^{288}$ National Labour Organization Representative 5 (2013 November 20): Personal Interview; International Labour Organization Executive 1 (2013 September 27): Personal Interview
} 
does not exist in a vacuum; it developed in the neoliberal era, with neoliberal interests and it now has a neoliberal character." ${ }^{289}$ As suggested, there are several aspects within the very structure of the EU that are founded in neoliberalism and explicitly disadvantageous for the working class. This is verified by the rulings of the European Court of Justice the European Union in the Laval, Viking, Luxembourg and Rüffert court cases, the monetary policy implemented by the European Central Bank, the policy instruments that were introduced in response to the crisis, the coercive force that the Troika applied on the crisis countries, and of course, the flexicurity, liberalization and austerity policies implemented by the Member States themselves. The fact that the language used by the European Union to justify the policy response was so similar to the language of BusinessEurope and completely contradicted the language of the ETUC speaks to the influence that capital has in the EU in contrast to the working class. ${ }^{290}$

The insight garnered from the interviews strongly suggests that the struggle of the labour movement is not institutional. The participants believed that the European labour movement is the most institutionally powerful in the world. They pointed out that labour organizations have not managed to construct such robust institutional forms of transnational representation in any other region in the world. Moreover, many EU Member States also host some of the most inclusive institutional forms of labour representation in the world. ${ }^{291}$ However, the cost of these institutional forms of representation was high. The ETUC in particular, supported the ratification of every EU treaty prior to the crisis. While the ETUC was able to make some gains it doing so, it essentially endorsed the creation of a EU that is fundamentally neoliberal, and in which organized labour is profoundly disadvantaged. ${ }^{292}$ Yet, the major problem faced by the movement

\footnotetext{
${ }^{289}$ International Labour Organization Executive 1 (2013 September 27): Personal Interview

${ }^{290}$ European-level Labour Organization Executive 2 (2013 September 26): Personal Interview

${ }^{291}$ European-level Labour Organization Executive 1 (2013 September 26): Personal Interview

${ }^{292}$ Labour Organization Executive 1 (2013, November 13): Personal Interview
} 
is its lack of structural power at the European level - its inability to coordinate workers across the continent. Its ability is so lacking that many research participants reported that neither EU institutions nor employer organizations respect organized labour. One international labour executive said "the elites do not fear the trade unions any more, they are glad as long as the unions are stuck bagging for a seat at the table."293

A representative of a national union stated that labour unions are not even respected as a distinct social partner as they once were, but are referred to as a "civil society group 99 times out of $100 " .{ }^{294}$ The perceived lack of respect of labour is due to the reduced ability of labour to apply pressure both in politics and in the production process. The marginalization of the Social Dialogue and the European Parliament has reduced the political/institutional power of the labour movement at the European level. ${ }^{295}$ Some even went as far as to say that neither the European Parliament nor the Social Dialogue ever had any power, they were created merely to make the European electorate and the trade union movement feel as if they had input in the political process. ${ }^{296}$ The problem with the labour movements, according to these views, is that it had based its strategy on institutional forms of power, and had not sufficiently maintained and constructed solidarity, the traditional base of trade union power. The lack of of pan-European solidarity has hindered attempts to organize transnationally and had sapped the structural power of the movement.

In order for labour to gain influence, the movement would have to be able to apply sustained pressure on the capitalist class and on policy makers at every level. The degree to

\footnotetext{
${ }^{293}$ International Executive - 1 (2013, September 27): Personal Interview

${ }^{294}$ National Representative - 5(2013, November 20): Personal Interview

${ }^{295}$ European-level Executive - 1 (2013, September 26): Personal Interview; EU Employee - 1 (2013, November 12): Personal Interview; National Representative - 5 (2013, November 20): Personal Interview ${ }^{296}$ National Executive - 1 (2013, November 13): Personal Interview; MEP - 1 (2013, November 12): personal interview; National Representative - 9 (2013, November 12): Personal Interview
} 
which it is able to do so will dependent on its ability to engage and mobilize the working class. This will require labour organizations to immerse themselves into a wider, working class movement that would ideally include unorganized workers, the unemployed, young people, students, as well as racialized peoples and others who are traditional excluded from labour struggles. However, the working class remains divided by identities that are built on differentiating experiences related to nationality, sector of employment, ethnicity and social status. In order to operate effectively on a European scale, perceptions of identity will have to be reimagined and founded on the shared experiences of workers across the EU. This is not to say that a 'European identity' will need to replace a spatially- or status- based identity. However, an identity that can at least co-exist with one's current perception of self will have to be developed on a transnational scale. ${ }^{297}$

The ETUC has engaged in strategically supporting the development of new social movements, which represents an alternative means to rebuilding structural power. We have already seen such movements develop into strong forces in national politics in Greece, Spain, and Italy, and support for other far left parties is growing in other countries across the EU. These coalitions allow trade unions to provide logistical support to social movements that are being built upon the current European context - on the current shared experience of Europeans. They present a real opportunity to build a European identify for the working class and thus a transnational working class movement - though it is unlikely that it will identify as such. The message of these groups is simple, it is that 'we are against neoliberalism, we want a system that works for the majority. ${ }^{298}$ It is worth noting though, that these movements have yet to develop a pathway to an alternative. This movement will be supported, not led by the unions. It is, and

\footnotetext{
${ }^{297}$ Brenner, 2009, 29-30

${ }^{298}$ National Labour Organization Executive 1 (2013 November 13): Personal Interview; EC Employee 4 (2013 December 2): Personal Interview
} 
always has been, the working class, and not trade unions that have the power to push back against capital. Trade unions, like all working class organizations have a role to play in that struggle, and they will continue to have a key role going forward. However, as always, the capacity to which they are able to forward their interests is directly dependent on the ability of these organizations to build, coordinate and utilize solidarity amongst the working class. 


\section{Citation Page:}

Abbott, Keith. "The ETUC and its Role in Advancing the Cause of European Worker Participation Rights." Economic and Industrial Democracy 19, no. 4 (1998): 605-631

Almeida Henrique and Anabela Reis. "Portugal Agrees to Sell REN Stake for 592 Billion Euros.” Bloomberg Business. 2 Feb. 2012. Web. 5 Apr. 2015.

$<$ http://www.bloomberg.com/news/articles/2012-02-02/portugal-agrees-to-sell-ren-stakefor-592-million-euros-1->

Arrighi, Giovanni. The long twentieth century: money, power, and the origins of our times. London: Verso, 1994.

Balme, Richard, and Didier Chabanet. European governance and democracy: power and protest in the EU. Lanham, Md.: Rowman \& Littlefield, 2008.

Banyuls, Josep and Albert Recio. "Spain: the Nightmare of Mediterranean Neoliberalism." $A$ Triumph of Failed Ideas: European Models of Capitalism in the Crisis. ed. Steffen Lehndorff. Brussels: ETUI Print shop. 2013. 199-219.

Benchmarking Working Europe 2013. Brussels: ETUI-REHS, 2013.

Brauninger, Dieter. "Privatisation in the Euro Area: Differing Attitudes towards Public Assets." Deutsche Bank Research. Deutsche Bank Management, 20 Aug. 2013. Web. 5 Apr. 2015. <https://www.dbresearch.com/PROD/DBR_INTERNET_ENPROD/PROD0000000000318583/Privatisation in the euro area: Differing attitud.pdf $>$.

Brandl, Bernd, and Franz Traxler. "Labour relations, economic governance and the crisis: turning the tide again?." Labor History 52, no. 1 (2011): 1-22.

Brenner, Neil. "A Thousand Leaves: Notes on Geographies of Uneven Spatial Development." In Leviathan undone? towards a political economy of scale. Vancouver [B.C.: UBC Press, 2009. 27-50.

Bücker, Andreas and Wiebke Warneck. "Viking - Laval - Rüffert: Consequences and policy perspectives." Brussels: ETUI Print shop. 2012

Busch, Klaus. Is the Euro failing? structural problems and policy failures bringing Europe to the brink. Berlin: Friedrich-Ebert-Stiftung, Internat. Policy Analysis, 2012.

"Capital Subscription." European Central Bank. European Union, 1 Jan. 2015. Web. 19 Mar. 2015. <https://www.ecb.europa.eu/ecb/orga/capital/html/index.en.html>.

Comas, Andrea. "Spain's Anti-austerity Podemos Neck-to-neck with Mainstream Parties: Poll." Reuters. Thomson Reuters, 12 Apr. 2015. Web. 12 Apr. 2015.

$<$ http://www.reuters.com/article/2015/04/12/us-spain-pollidUSKBN0N30C220150412>.

"COUNCIL RECOMMENDATIONS on Spain's 2012 National Reform Programme and Delivering a Council Opinion on Spain's Stability Programme for 2012-2015." European Commission. European Union, 30 May 2012. Web. 5 Apr. 2015. $<$ http://ec.europa.eu/europe2020/pdf/recommendations_2011/csr_spain_en.pdf $>$. Degryse, Christophe, and Pierre Tilly. 1973-2013: 40 years of history of the European Trade Union Confederation. Brussels: ETUI, 2013. 
Dullien, Sebastian. "Reinventing Europe: Explaining the Fiscal Compact." European Council on Foreign Relations. European Council on Foreign Relations, 1 May 2012. Web. 26 Apr. 2015.

$<\mathrm{http}: / /$ www.ecfr.eu/article/commentary_reinventing_europe_explaining_the_fiscal_com pact>.

Duménil, Gerard, and Dominque Lévy. "The Nature and Contradictions of Neoliberalism." Socialist Register 38 (2009): 43-71

Edelman, Marc. "Transnational Organizing in Agrarian Central America: Histories, Challenges, Prospects." Journal of Agrarian Change 8, no. 2-3 (2008): 229-257.

European Coal and Steel Community (ECSC) | European organization. (2014, May 25).

Retrieved January 28, 2015, from

http://www.britannica.com/EBchecked/topic/196004/European-Coal-and-Steel-

Community-ECSC

European Commission. "Six-pack? Two-pack? Fiscal compact? A short guide to the new EU

fiscal governance." Economic and Financial Affairs.

http://ec.europa.eu/economy_finance/articles/governance/2012-03-14_six_pack_en.htm (accessed April 14, 2014).

European Commission (a) "Europe 2020." European Commission, 26 Feb. 2015. Web. 25 Apr.

2015. <http://ec.europa.eu/europe2020/making-it-happen/index_en.htm>.

European Commission (b). Country Specific Report 2015. Brussels: European Comission, 2015.

European Commission (c) Commission Staff Working Document: Assessment of the 2014

national reform programme for Greece. European Commission. 2014

"Communication From the European Commission to the European Parliament, The Council, The European Central Bank and the Eurogroup." European Commission. European Union, 26 Feb. 2015. Web. 25 Apr. 2015.

$<$ http://ec.europa.eu/europe2020/pdf/csr2015/cr2015_comm_en.pdf $>$.

Eriksson, Jonas, and Monika Hjeds Lofmark. Crisis Management in the EU: Strengthening

Economic Governance and Financial Stability. Stockholm: Swedish Institute for

European Policy Studies, 2013. Print.

European Parliament. "The Port Services Directive." European Parliament. http://www.europarl.europa.eu/sides/getDoc.do?pubRef=-//EP//TEXT+IM-

PRESS+20060124BKG04626+0+DOC+XML+V0//EN (accessed April 2, 2014).

European Trade Union Confederation. "What is the ETUC?." European Trade Union

Confederation.

http://www.etuc.org/sites/www.etuc.org/files/other/files/fiches_presentation_gb_web.pd $\mathrm{f}$ (accessed March 18, 2014).

European Union. "Single European Act," 17 February, 2007. European Union Treaties and Other International Agreements.

European Union. "Treaty of Lisbon," 13 December 2007. European Union Treaties and Other International Agreements 
OECD. "Trade Union Density." Trade Union Density. http://stats.oecd.org/Index.aspx?DataSetCode=UN_DEN\# (accessed April 14, 2014).

“The European Semester." European Commission. European Union. 27 March. 2015. Web. 3 April 2015 from: http://ec.europa.eu/economy_finance/economic_governance/the_european_semester/ind ex_en.htm

Fulton, L. "Across Europe." National Industrial Relations. http://www.worker-

participation.eu/National-Industrial-Relations/Across-Europe (accessed April 14, 2014).

Greenwood, Justin. Interest representation in the European Union. Third Edition ed.

Houndmills, Basingstoke, Hampshire: Palgrave Macmillan, 2011.

Guimardes, Pedro. "Portugal". Labour Market Reforms Tracker. London: Freshfields Brukhaus Deringer LLP. 2014. 31-35

Harvey, David. The Limits to Capital. New York: Verso. 2006.

Heyes, Jason. "Flexicurity in crisis: European labour market policies in a time of austerity." European Journal of Industrial Relations 19, no. 1 (2013): 71-86.

Horn, Laura. "Anatomy of a Critical Friendship: Organized Labour and the European State Formation." Globalizations 9, no. 4 (2012): 577-592.

Jessop, Bob. "Liberalism, Neoliberalism, and Urban Governance: A State-Theoretical

Perspective." Eprints. University of Lancaster, 2002. Web. 25 Apr. 2015.

$<$ http://eprints.lancs.ac.uk/173/2/E-2002a_antipode.pdf $>$.

Karamessini, Maria. "Sovereign Debt Crisis: An Opportunity to Complete the Neoliberal Project and Dismantle the Greek Employment Model." A Triumph of Failed Ideas: European Models of Capitalism in the Crisis. Ed. Steffen Lehndorff. Brussels: ETUI Printshop, 2012. 155-182.

Langford, Kevin. "Ireland". Labour Market Reform Tracker. London: Freshfields Brukhaus Deringer LLP. 2014: 22-23

Larsson, Bengt. "Obstacles to transnational trade union cooperation in Europe-results from a European survey." Industrial Relations Journal 43, no. 2 (2012): 152-170.

Heyes, Jason. "Flexicurity in crisis: European labour market policies in a time of austerity." European Journal of Industrial Relations 19, no. 1 (2013): 71-86.

Mahon, Rianne. "Canadian public policy: the unequal structure of representation." In The Canadian state: political economy and political power. Toronto: University of Toronto Press, 1977. 165-198.

Mahon, Rianne. "Of Scalar hierarchies and Welfare Redesign: Child Care in Four Canadian Cities." In Leviathan Undone? Towards a Political Economy of Scale. Vancouver: UBC Press, 2009. 209-228.

Marx, Karl, and Friedrich Engels. Capital; a critique of political economy. 1867. Reprint, New York: Penguin Books, 1982.

Marx, Karl and Friedrich Engels. The Communist Manifesto. Harmondsworth: Penguin Books, 1967 
Meiksins Wood, Ellen. "Capitalism and Human Emancipation." New Left Review 167, no. 1 (1988): 3-20.

Moussis, Nicholas. "Europedia - The Euro Plus Pact." Europedia. European Study Service, 2011.

Web. 25 Apr. 2015. <http://www.europedia.moussis.eu/discus/discus-1241513297448911-32221.tkl>.

OECD. "Trade Union Density." Trade Union Density. http://stats.oecd.org/Index.aspx?DataSetCode=UN_DEN\# (accessed April 14, 2014).

The Open Method of Coordination. (n.d.). Retrieved January 15, 2015, from

http://europa.eu/legislation_summaries/glossary/open_method_coordination_en.html

Otero, Geraldo. "Neoliberal Reform in Rural Mexico: Social Structural and Political

Dimensions." Latin American Research Review 35, no. 1 (1999): 187-207.

Otero, Gerardo. Mexico in transition: neoliberal globalism, the state and civil society. Black

Point, Nova Scotia: Fernwood Pub. ;, 2004.

Panitch, Leo. American empire and the political economy of global finance. Houndmills, Basingstoke, Hampshire England: Palgrave Macmillan. 2008

Panitch, Leo and Sam Gindin. "The Current Crisis: A Socialist Perspective." Studies in Political Economy 83 (2009): 7-31.

Polanyi, Karl. The Great Transformation. 1st Beacon paperback ed. Boston: Beacon Press, 1944.

Political Poll Archives: Europe." Metapolis: The World of Polls. Meapolis. Web. 13 Apr. 2015. $<$ http://metapolls.net/category/europe $>$.

Porter, Eduardo. "Americanized Labor Policy Is Spreading in Europe." The New York Times,

December 3, 2013. http://www.nytimes.com/2013/12/04/business/economy/theamericanization-of-european-labor-

policy.html?pagewanted $=1 \&$ r $=0 \&$ adxnnl=1\&adxnnlx $=1395961216$ -

sTUoDNAvRSH0YRQUwDP2XA (accessed March 21, 2014).:

Patel, Rajeev. "International Agrarian Restructure and the Practical Ethics of Peasant Movement Solidarity." Journal of Asian and African Studies 41, no. 1-2 (2006): 71-93.

"Company Overview of REN - Redes Energéticas Nacionais, SGPS, S.A.” Bloomberg Snapshot. Bloomberg Business. 4 Apr. 2015 Web. 5 Apr. 2015.

$<$ http://www.bloomberg.com/research/stocks/private/snapshot.asp?privcapId=5468837>

"European Trade Union Confederation." Composition and Organization. European Trade Union

Confederation. Web. 12 Apr. 2015. <http://www.etuc.org/composition-andorganisation $>$.

Ross, George, and Andrew Martin. The Brave New World of European Labour: European Trade Unions at the Millenium. Oxford, NY: Berghahn Books, 1999.

Rowen, Herbert. 'L'Etat c'est a moi: Louis XIV and the State.” French Historical Studies 2, no. 1. (1961): 83-98

"State Aid Scoreboard 2014 Aid in the Context of the Financial and Economic Crisis." European Commission. European Union, 17 Dec. 2014. Web. 7 Apr. 2015.

$<$ http://ec.europa.eu/competition/state_aid/scoreboard/financial_economic_crisis_aid_en 
.html>.

Smith, Neil. Uneven development: nature, capital, and the production of space. New York, NY: Blackwell, 2008.

"Survey - Paid Vacations \& Holidays in OECD Countries - Radius." Survey - Paid Vacations \&amp; Holidays in OECD Countries - Radius. Centre for Economic Policy Research, 18 June 2013. Web. 9 Apr. 2015.

Swartz, Donald, and Rosemary Warskett. "Canadian Labour and the Crisis of Solidarity." In Rethinking the politics of labour in Canada. Halifax: Fernwood Publishing, 2012. 1-22.

Time. "Eurozone Unemployment, Inflation Stable." Time. http://business.time.com/2014/02/28/eurozone-unemployment-inflation-stable/ (accessed March 21, 2014).

Tsvetkov, Peter. "CTT, Annual Report 2014" Correios de Portugal. 2014 Web. 5 Apr. 2015: < http://www.ipc.be/ /media/Documents/PUBLIC/annual-reports/memberreports/2014/CTT-Correios\%202014.pdf>

Treaty establishing the European Economic Community, EEC Treaty - original text. (2010, October 15). Retrieved January 29, 2015, from

http://europa.eu/legislation_summaries/institutional_affairs/treaties/treaties_eec_en.htm

Treaty establishing the European Coal and Steel Community, ECSC Treaty. (2014, October 15).

Retrieved January 29, 2015, from

http://europa.eu/legislation_summaries/institutional_affairs/treaties/treaties_ecsc_en.htm

Turner, Thomas, and Daryl D'Art. "Public Perceptions of Trade Unions in Countries of the European Union A Casual Analysis." Labour Studies Journal 37, no. 1 (2012): 33-55.

Vandaele, Kurt. Sustaining or Abandoning 'social peace'? Strike development and trends in Europe since the 1990s. Brussels: European Trade Union Institution, 2011

Vogiatzoglou, Markos. Trade Unions in Greece: Protest and Social Movements in the Context of Austerity Politics. 2014. San Demenico di Fiesole, Italy: European University Institute.

Waddington, Jeremy, and Reiner Hoffmann. "Reform, Organizing and Restructuring." Trade unions in Europe: Meeting the Challenge. Brussels: P.I.E - Peter Lang, 2003. 33-63.

Wahl, Asbjorn. "European Labor: Political and Ideological Crisis in an Increasingly More Authoritarian European Union." Monthly Review 65, no. 8 (2014). http://monthlyreview.org/2014/01/01/european-labor (accessed March 3, 2014).

Wahl, Asbjorn. The rise and fall of the welfare state. London: Pluto Press, 2011.

Zacune, Joseph. "Privatizing Europe, Using the Crisis to Entrench Neoliberalism." TNI.org. Transnational Institute, 1 Mar. 2013. Web. 24 Mar. 2015. $<$ http://www.tni.org/files/download/privatising_europe.pdf $>$. 